\title{
Membrane bioreactors for hospital wastewater treatment: recent advancements in membranes and processes
}

\author{
Yan Zhao ${ }^{1}$, Yangbo Qiu ${ }^{2}$, Natalie Mamrol ${ }^{3}$, Longfei Ren ${ }^{2}$, Xin $\mathrm{Li}^{1}$, Jiahui Shao $(\bowtie)^{2}$, Xing Yang (凶) ${ }^{1}$, \\ Bart van der Bruggen $(\bowtie)^{1}$ \\ 1 Department of Chemical Engineering, KU Leuven, B-3001 Leuven, Belgium \\ 2 School of Environmental Science and Engineering, Shanghai Jiao Tong University, Shanghai 200240, China \\ 3 Department of Materials Science and Engineering, Massachusetts Institute of Technology, Cambridge, MA 02139, USA
}

(C) Higher Education Press 2021

\begin{abstract}
Discharged hospital wastewater contains various pathogenic microorganisms, antibiotic groups, toxic organic compounds, radioactive elements, and ionic pollutants. These contaminants harm the environment and human health causing the spread of disease. Thus, effective treatment of hospital wastewater is an urgent task for sustainable development. Membranes, with controllable porous and nonporous structures, have been rapidly developed for molecular separations. In particular, membrane bioreactor (MBR) technology demonstrated high removal efficiency toward organic compounds and low waste sludge production. To further enhance the separation efficiency and achieve material recovery from hospital waste streams, novel concepts of MBRs and their applications are rapidly evolved through hybridizing novel membranes (non hydrophilic ultrafiltration/microfiltration) into the MBR units (hybrid MBRs) or the MBR as a pretreatment step and integrating other membrane processes as subsequent secondary purification step (integrated MBR-membrane systems). However, there is a lack of reviews on the latest advancement in MBR technologies for hospital wastewater treatment, and analysis on its major challenges and future trends. This review started with an overview of main pollutants in common hospital wastewater, followed by an understanding on the key performance indicators/criteria in MBR membranes (i.e., solute selectivity) and processes (e.g., fouling). Then, an in-depth analysis was provided into the recent development of hybrid MBR and integrated MBR-membrane system concepts, and applications correlated with wastewater sources, with a particular focus on hospital wastewaters. It is anticipated that this review will shed light on the
\end{abstract}

Received June 22, 2021; accepted August 15, 2021

E-mails: jhshao@sjtu.edu.cn (Shao J), xing.yang@kuleuven.be (Yang X), Bart.VanderBruggen@kuleuven.be (van der Bruggen B) knowledge gaps in the field, highlighting the potential contribution of hybrid MBRs and integrated MBRmembrane systems toward global epidemic prevention.

Keywords membrane technology, membrane bioreactor, hospital wastewater, hybrid MBR, integrated MBR-membrane system

\section{Introduction}

Coronavirus disease 2019 (COVID-19) is an acute respiratory tract infection caused by a novel coronavirus (SARS-CoV-2). This disease has rapidly transmitted worldwide and has been declared a global pandemic by the World Health Organization (WHO) [1,2], and currently has already led to more than 3500000 deaths. Worldwide measures for treating and preventing COVID-19 spread have been enforced. Including intense epidemiology research, new political policies, and pandemic mitigation techniques, which have achieved initial success and slowed down the infection rate [3]. However, vaccine research efforts and patient hospitalization consume large quantities of disinfectants, drugs and other medical substances, leading to an enormous amount of discharged hospital wastewater that may ultimately transfer into the water system [4]. Generally, the hospital wastewater contains viruses/bacteria, pathogenic microorganisms, antibiotic groups, partially metabolized pharmaceutical substances, organic compounds, radioactive elements, and ion pollutants [5-7]. In fact, several case studies have reported fecal-oral transmission through wastewater as a possible vector of COVID-19 [8].

The byproduct pollutants from epidemic prevention, may lead to environmental issues and eventually deteriorate human health [9]. Therefore, effective treatment of 
hospital wastewater is also an important step to prevent the spread of diseases. The traditional methods used in hospital wastewater treatment to destroy bacteria and viruses include disinfection (e.g., ozone and chlorine, sodium hypochlorite) and chlorine dioxide detoxification [10-13]. However, drugs, harmful ions, antivirals, antibacterial, and other toxic substances still remain in the hospital wastewater after the above disinfection steps. More aggressive approaches are adopted, such as high-temperature calcination, evaporation and precipitation, which may be helpful but come with high cost, environmental strain, and low efficiency. Thus, these drawbacks greatly limit the applications of these technologies in hospital wastewater treatment [14].

Membrane separation is an advanced technology in hospital wastewater treatment because of its high solute selectivity, relatively low energy consumption, easy scalability, and attractive process economics $[15,16]$. Membranes have been widely used in wastewater treatment to separate contaminants (such as bacteria and protozoa) or ions [17-19].

Membrane bioreactors (MBRs) mainly consist of the activated sludge process and microfiltration/ultrafiltration (UF/MF) membranes filtration for wastewater treatment and recycling. Compared to a conventional activated sludge treatment system, the secondary settling tank and sand filtration system are replaced by UF/MF membranes in the classical MBR processes. MBRs remove viruses from wastewater through a combined mechanism: steric removal, adsorption, and inactivation during biological treatment [20]. Consequently, MBRs have shown increased removal of enteric viruses in comparison to activated sludge treatment [21]. Also, MBR technology shows cost-effective with higher efficiency and low energy consumption [22], providing an advanced method to effectively separate complex contaminant mixtures and pathogenic microbes from wastewater [23].

Traditional MBRs can effectively remove activated sludge and some macromolecular organic substances [24]. However, this technology still faces challenges such as high membrane fouling propensity and low micromolecular rejection $[25,26]$. Many harmful microorganisms or ionic species are present in hospital wastewater, requiring thorough disinfection $[27,28]$. With a sustainable mindset, there is emerging interest to simultaneously remove harmful substances and recover valuable components (e.g., radioactive elements) [29]. These may require the further adaptation of the MBR units by hybridizing novel membranes (non hydrophilic UF/MF), namely hybrid MBRs; or the MBR as a pretreatment step and integrating other membrane processes as subsequent secondary purification step (e.g., nanofiltration (NF), reverse osmosis (RO), electrodialysis (ED)), namely integrated MBR-membrane systems [30,31]. With a particular interest on hospital wastewater treatment, tremendous efforts have been made to carefully design the MBRs to achieve high separation efficiency and various purification purposes, by enhancing the solute selectivity (or rejection) and membrane flux, as well as reducing the fouling tendency $[32,33]$.

However, there is a lack of reviews on the latest advancement in MBR technologies designed for hospital wastewater treatment, and analysis on its major challenges and future trends. This review starts with an overview of main pollutants in common hospital wastewater, follows by an understanding on the key performance indicators/ criteria in MBR membranes (i.e., solute selectivity) and processes (e.g., fouling). Then, an in-depth analysis was provided into the recent development of the concepts on hybrid MBRs and integrated MBR-membrane systems, and applications correlated with wastewater sources, with a particular focus on hospital wastewaters. It is anticipated that this review will shed light on the knowledge gaps in the field, highlighting the potential contribution of hybrid MBRs and integrated MBR-membrane systems toward global epidemic prevention.

\section{Components of hospital wastewater}

Hospitals and medical activities use purified water every day, leading to the discharge of a high volume of hospital wastewater. This hospital wastewater contains complicated compounds from diagnostic activities, laboratory research, epidemic prevention/sanitation, and medicine excretion. Depending on a variety of toxic or persistent substances, the components of typical hospital wastewater include pathogenic microorganisms (e.g., coronavirus, enterovirus, hepatitis A virus, Staphylococcus aureus, sulfite-reducing anaerobes), antibiotic groups (e.g., enrofloxacin, ciprofloxacin, oxalinic, ofloxacin, norfloxacin, sulphapyridine, trimethoprim, metronidazole, and their metabolites), common organic compounds pollutants (e.g., pharmaceutical residues, carbohydrates, proteins, amino acids, generic drugs, esters, organic solvents), and ionic pollutants (e.g., heavy metals, contrast agents) [34], as shown in Fig. 1.

\subsection{Pathogenic microorganisms}

Viruses are composed of internal nucleic acids surrounded by a protective protein coating and typically have diameters between 20 and $300 \mathrm{~nm}$ (some filoviruses have a total length around $1400 \mathrm{~nm}$ ). Due to their sizes, viruses are difficult to detect, isolate and classify [35]. However, they are the most abundant biological entities in our biosphere and play a significant role in genetic diversity [36]. Furthermore, viruses rely on a range of hosts to survive and repopulate and impart considerable reactions, sometimes averse to the host, called cytopathic effects [37]. Virus transmission in different organisms requires mobile media; for example, COVID-19 may spread 


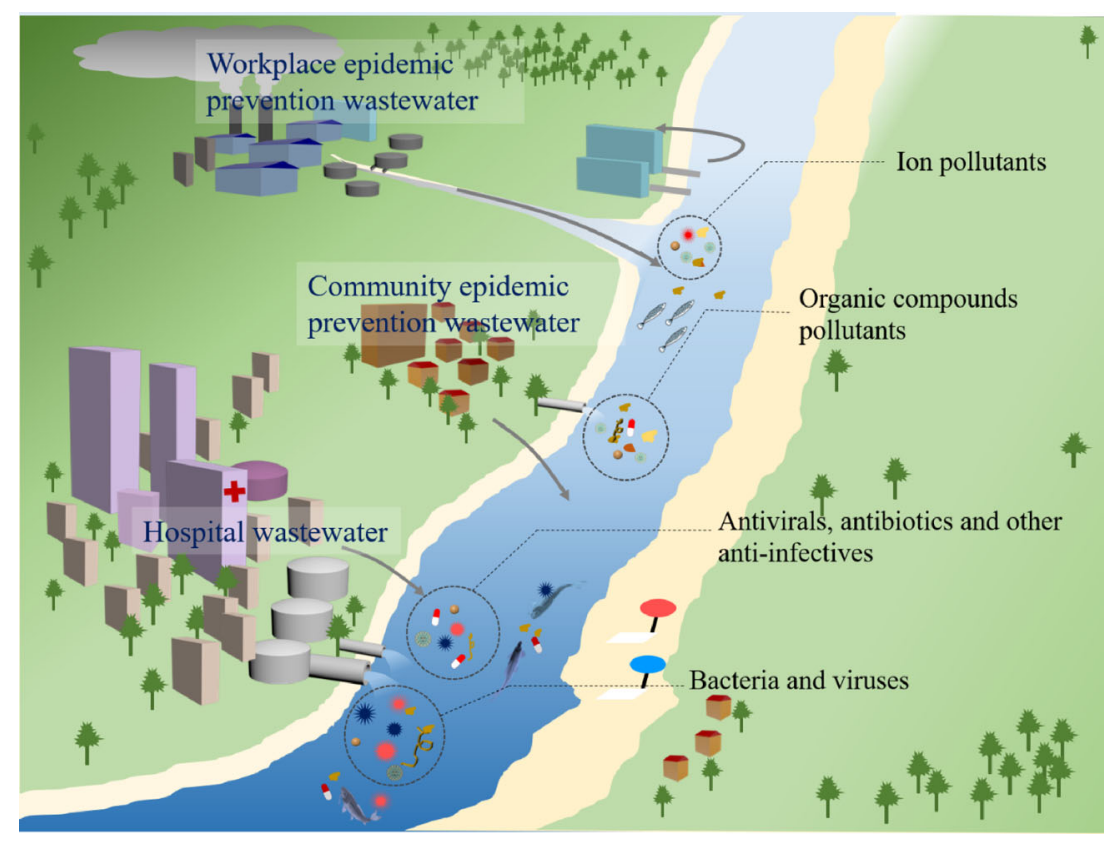

Fig. 1 The hospital wastewater, community epidemic prevention, and workplace epidemic prevention containing large amounts of water-borne bacteria and viruses, antivirals, antibacterial, and other anti-infectives, organic compounds, and ionic pollutants.

between humans through direct or indirect contact, respiratory droplets, and possibly, through fecal-oral transmission. A separate study revealed that coronavirus could remain infectious in wastewater for days to weeks [38] and contaminated water may also increase the risk of transmission.

Unlike viruses, bacteria are larger (typically several micrometers in length) and have a cellular structure. Bacteria can inhabit in water, soil, and gaseous environments and contribute to symbiotic and parasitic relationships with plants, animals, and humans [35]. Many of them are rendered harmless, but several species of bacteria are pathogenic and cause infectious diseases (e.g., Staphylococcus aureus, sulfite-reducing anaerobes) [39]. Due to the high concentration of viruses or bacteria in the hospital wastewater, the development of highly efficient methods or technologies to remove these viruses or bacteria enables fully effective transmission and infection control of contaminated water. Table 1 shows the many typical water-borne viruses and bacteria in hospital wastewater and their typical concentration range in various wastewater sources. Their upper concentration limits in the treated water defined by WHO, i.e., effluent from treatment plans, are also given in the table.

\subsection{Antibiotic groups}

Antibiotic groups, including antivirals, antibacterial, and other anti-infectives, are the most common medicines. When an infection is linked to an unidentified pathogen in clinical treatment, empiric therapies using large quantities of antivirals or antibacterial are used to treat the patients in these emergencies, sometimes within a short period $[72,73]$. Recently, many hospitals and research facilities have been required to reduce the application of these medicines for several reasons. First, according to numerous studies, researchers confirmed these drugs have heavily leached into the environment in the past 20 years [74]. Secondly, the effluent from hospital wastewater has been regarded as the primary source for the spread of antiviral- and antibacterial-resistance genes [75]. Table 2 shows a list of discharged antivirals, antibacterial, antimycotics, and metabolites in hospital wastewater. For example, when antivirals, antibacterial, and other antiinfectives are not completely metabolized in patients, they are excreted via feces or urine, which enter the environment through wastewater discharge [76]. Sometimes, this wastewater comes from hospitals due to their high volume of care and is tainted with unmetabolized species due to high drug consumption [77]. Especially during the pandemic, the large loading and high concentration of antivirals, antibacterial, and other anti-infectives in wastewater enter rivers or lakes due to low-efficiency separation in WWTPs [78]. This kind of wastewater discharge may incur potential ecosystem alterations (including toxicity toward algae, daphnids, and fish) and the development of virus and bacteria resistant microbes (Fig. 1) [79]. Once released into the waterways, these drugs are consumed by birds, poultry, livestock, and other animals and even present in drinking water, thus posing a threat to human health $[78,80]$. The unmetabolized medicines in wastewater also represent a waste of hospital resources. Medicine's repurposing, in which the effective drug is extracted from the wastewater, may resolve the pollution 
Table 1 Recently reported typical water-borne viruses and bacteria in hospital wastewater

\begin{tabular}{|c|c|c|c|}
\hline$\overline{\text { Name }}$ & Molecular size & $\begin{array}{l}\text { Hopstial wastewater treatment plant (WWTP) } \\
\text { sample concentration }\end{array}$ & Ref. \\
\hline \multicolumn{4}{|l|}{$\begin{array}{l}\text { Virus } \\
\end{array}$} \\
\hline Adenovirus & Diameter: $70-100 \mathrm{~nm}$ & $2.02 \times 10^{6}$ to $7.23 \times 10^{6} \mathrm{GC} \cdot \mathrm{mL}^{-1}$ a) & [40-42] \\
\hline Astrovirus & Diameter: $28 \mathrm{~nm}$ & $6.3 \%$ (of total influent samples) & {$[40,43,44]$} \\
\hline Coronavirus (SARS-CoV-2) & Diameter: $60-140 \mathrm{~nm}$ & Confirmed, but not quantified & {$[40,45,46]$} \\
\hline $\begin{array}{l}\text { Enteroviruses (echovirus, coxsackie } \\
\text { viruses, poliovirus) }\end{array}$ & Diameter: $25-30 \mathrm{~nm}$ & $2.6 \times 10^{6} \mathrm{GC} \cdot \mathrm{mL}^{-1}$ & {$[40,47,48]$} \\
\hline Hepatitis $\mathrm{A} / \mathrm{E}$ & Diameter: $27-30 \mathrm{~nm}$ & $2.8 \times 10^{4} \mathrm{GC} \cdot \mathrm{mL}^{-1}$ & {$[40,49]$} \\
\hline Norovirus I/II & Diameter: $27-38 \mathrm{~nm}$ & $3.1 \%$ (of total influent samples) & {$[40,44,50]$} \\
\hline Rotavirus & Diameter: $75 \mathrm{~nm}$ & $32.3 \%$ (of total influent samples) & {$[40,44,51]$} \\
\hline Sapovirus & Diameter: $41-46 \mu \mathrm{m}$ & $29.4 \%$ (of total influent samples & {$[40,52,53]$} \\
\hline \multicolumn{4}{|l|}{ Protozoa } \\
\hline Cryptosporidium & Diameter: $3-14 \mu \mathrm{m}$ & $18.9 \%$ (of total influent samples) & {$[40,54,55]$} \\
\hline Entamoeba histolytica & Diameter: $3-14 \mu \mathrm{m}$ & $59 \%$ (of total influent samples) & {$[40,56,57]$} \\
\hline Giardia duodenalis & Diameter: $3-14 \mu \mathrm{m}$ & $27.4 \%$ (of total influent samples) & {$[40,55,58]$} \\
\hline \multicolumn{4}{|l|}{ Bacteria } \\
\hline Campylobacter & $\begin{array}{l}\text { Diameter: } 0.2-0.4 \mathrm{~mm} \\
\text { Length: } 0.5-5 \mathrm{~mm}\end{array}$ & $87 \%$ (of total influent samples) & {$[59,60]$} \\
\hline Escherichia coli & $\begin{array}{l}\text { Diameter: } 0.2-6.0 \mu \mathrm{m} \\
\text { Length: } 1.1-1.1 \mu \mathrm{m}\end{array}$ & $4.6 \times 10^{6} \mathrm{CFU} \cdot \mathrm{mL}^{-1 \mathrm{~b})}$ & {$[40,61,62]$} \\
\hline Legionella & $\begin{array}{l}\text { Diameter: } 0.3-0.9 \mu \mathrm{m} \\
\text { Length: } 1-3 \mu \mathrm{m}\end{array}$ & $58 \%$ (of total influent samples) & {$[63,64]$} \\
\hline Pseudomonas & $\begin{array}{l}\text { Diameter: } 0.6-1.2 \mu \mathrm{m} \\
\text { Length: } 2-3 \mu \mathrm{m}\end{array}$ & 2 to $800 \mathrm{CFU} \cdot \mathrm{mL}^{-1}$ & {$[40,65]$} \\
\hline Salmonella & $\begin{array}{l}\text { Diameter: } 0.8-1.5 \mu \mathrm{m} \\
\text { Length: } 2-5 \mu \mathrm{m}\end{array}$ & $71 \%$ (of total influent samples) $/ 5.5 \times 10^{4} \mathrm{CFU} \cdot \mathrm{g}^{-1}$ & {$[40,66-68]$} \\
\hline Shigella & $\begin{array}{l}\text { Diameter: } 0.6-1.2 \mu \mathrm{m} \\
\text { Length: } 2-3 \mu \mathrm{m}\end{array}$ & $62 \%$ (of total influent samples) $/ 2.2 \times 10^{5} \mathrm{CFU} \cdot \mathrm{g}^{-1}$ & {$[40,67-69]$} \\
\hline Streptococcus & $\begin{array}{l}\text { Diameter: } 0.6-1.2 \mu \mathrm{m} \\
\text { Length: } 2-3 \mu \mathrm{m}\end{array}$ & $1.6 \times 10^{5} \mathrm{CFU} \cdot \mathrm{g}^{-1}$ & {$[40,68]$} \\
\hline Vibrio cholera & $\begin{array}{l}\text { Diameter: } 0.6-1.2 \mu \mathrm{m} \\
\text { Length: } 0.5-3 \mu \mathrm{m}\end{array}$ & 0.01 to $10 \mathrm{CFU} \cdot \mathrm{mL}^{-1}$ & {$[40,70,71]$} \\
\hline
\end{tabular}

a) $\mathrm{GC} \cdot \mathrm{mL}^{-1}$ : genome copies per milliliter; b) $\mathrm{CFU} \cdot \mathrm{mL}^{-1}$ : colony-forming units per milliliter.

issue, and significantly reduce medication costs $[81,82]$. Therefore, a novel technology for highly efficient selective separation and extraction of the target medicines is needed.

\subsection{Organic compounds}

Hospital wastewater contains a large variety of small (100 $1000 \mathrm{Da})$ organic compounds, including carbohydrates, proteins, amino acids, generic drugs, esters, and organic solvents, which are widely discharged into surface waters and drinking water sources $[88,89]$. These organic compounds pose a direct threat to human health through drinking or irrigation water. Another significant threat from these organic compounds is their large volume generated in wastewater, resulting in oxygen deficiency and mutagenic properties in aquatic environments [90,91]. Some of the organic compounds are considered persistent pollutants due to their low biodegradability and high adsorption affinity in aquatic ecosystems, such as caffeine, tramadol, and iopromide [92]. These organic compounds in hospital wastewater have become one of the most extensively studied classes of emerging organic contaminants in aquatic environments. The common and persistent organic compounds in hospital wastewater are list in Table 3. Unfortunately, the traditional methods based on disinfection, flotation, and clarification do not effectively remove these organic micropollutants [93]. Only a very small fraction of these hospital organic compounds is removed from WWTPs [94]. Hence, efficient technologies to remove these persistent organic compounds including pharmaceuticals, from wastewater are highly desirable. 
Table 2 Discharged antivirals, antibacterials, antimycotics, and metabolites in hospital wastewater

\begin{tabular}{|c|c|c|c|c|}
\hline Name & Chemical formula & Size $/\left(\mathrm{g} \cdot \mathrm{mol}^{-1}\right)$ & $\begin{array}{l}\text { Hopstial WWTPs sample concentration/ } \\
\left(\mathrm{ng} \cdot \mathrm{L}^{-1}\right)\end{array}$ & Ref. \\
\hline \multicolumn{5}{|l|}{ Antibacterials } \\
\hline Azythromycin & $\mathrm{C}_{38} \mathrm{H}_{72} \mathrm{~N}_{2} \mathrm{O}_{12}$ & 748.98 & $20.1 \pm 5.7$ & {$[83,84]$} \\
\hline Carbamazpine & $\mathrm{C}_{15} \mathrm{H}_{12} \mathrm{~N}_{2} \mathrm{O}$ & 236.27 & 14 & {$[84]$} \\
\hline Cefotaxime & $\mathrm{C}_{16} \mathrm{H}_{17} \mathrm{~N}_{5} \mathrm{O}_{7} \mathrm{~S}_{2}$ & 455.5 & $143.7 \pm 4.2$ & [83] \\
\hline Ceftazidime & $\mathrm{C}_{22} \mathrm{H}_{22} \mathrm{~N}_{6} \mathrm{O}_{7} \mathrm{~S}_{2}$ & 636.7 & 1200 & [85] \\
\hline Cefazolin & $\mathrm{C}_{14} \mathrm{H}_{14} \mathrm{~N}_{8} \mathrm{O}_{4} \mathrm{~S}_{3}$ & 454.5 & $83.4 \pm 3.6$ & [83] \\
\hline Ciprofloxacin & $\mathrm{C}_{17} \mathrm{H}_{18} \mathrm{FN}_{3} \mathrm{O}_{3}$ & 331.34 & $8372.9 \pm 67.8$ & {$[83,84,86]$} \\
\hline Chlortetracycline & $\mathrm{C}_{22} \mathrm{H}_{23} \mathrm{ClN}_{2} \mathrm{O}_{8}$ & 478.88 & 8 & {$[84]$} \\
\hline Clarithromycin & $\mathrm{C}_{38} \mathrm{H}_{69} \mathrm{NO}_{13}$ & 747.95 & $167.3 \pm 10.7$ & {$[83,84]$} \\
\hline Doxycycline & $\mathrm{C}_{22} \mathrm{H}_{24} \mathrm{~N}_{2} \mathrm{O}_{8}$ & 444.44 & 18 & {$[84]$} \\
\hline Enrofloxacin & $\mathrm{C}_{19} \mathrm{H}_{22} \mathrm{FN}_{3} \mathrm{O}_{3}$ & 359.4 & 4 & {$[84]$} \\
\hline Erythromycin & $\mathrm{C}_{37} \mathrm{H}_{65} \mathrm{NO}_{12}$ & 715.92 & $188 \pm 297$ & {$[84,87]$} \\
\hline Lomefloxacin & $\mathrm{C}_{17} \mathrm{H}_{19} \mathrm{~F}_{2} \mathrm{~N}_{3} \mathrm{O}_{3}$ & 351.35 & 10 & [84] \\
\hline Metronidazole & $\mathrm{C}_{6} \mathrm{H}_{9} \mathrm{~N}_{3} \mathrm{O}_{3}$ & 171.15 & $937.4 \pm 111.8$ & {$[83]$} \\
\hline Norfloxacin & $\mathrm{C}_{16} \mathrm{H}_{18} \mathrm{FN}_{3} \mathrm{O}_{3}$ & 319.33 & $5933 \pm 3390$ & {$[84,86]$} \\
\hline Ofloxacin & $\mathrm{C}_{18} \mathrm{H}_{20} \mathrm{FN}_{3} \mathrm{O}_{4}$ & 361.37 & $14377.8 \pm 50.9$ & {$[83,84]$} \\
\hline Oxytetracycline & $\mathrm{C}_{22} \mathrm{H}_{24} \mathrm{~N}_{2} \mathrm{O}_{9}$ & 460.43 & 18 & {$[84]$} \\
\hline Roxithromycin & $\mathrm{C}_{41} \mathrm{H}_{76} \mathrm{~N}_{2} \mathrm{O}_{15}$ & 837.05 & 23 & {$[4]$} \\
\hline Spiramycin & $\mathrm{C}_{43} \mathrm{H}_{74} \mathrm{~N}_{2} \mathrm{O}_{14}$ & 843.1 & 1700 & [85] \\
\hline Sulfadiazine & $\mathrm{C}_{10} \mathrm{H}_{10} \mathrm{~N}_{4} \mathrm{O}_{2} \mathrm{~S}$ & 250.28 & $1896 \pm 4003$ & [87] \\
\hline Sulfadimidine & $\mathrm{C}_{12} \mathrm{H}_{14} \mathrm{~N}_{4} \mathrm{O}_{2} \mathrm{~S}$ & 278.33 & 59 & {$[84]$} \\
\hline Sulfamethoxazole & $\mathrm{C}_{10} \mathrm{H}_{11} \mathrm{~N}_{3} \mathrm{O}_{3} \mathrm{~S}$ & 253.27 & 9800 & {$[84,85]$} \\
\hline Sulfapyridine & $\mathrm{C}_{11} \mathrm{H}_{11} \mathrm{~N}_{3} \mathrm{O}_{2} \mathrm{~S}$ & 249.29 & 251 & {$[87]$} \\
\hline Tetracycline & $\mathrm{C}_{22} \mathrm{H}_{24} \mathrm{~N}_{2} \mathrm{O}_{8}$ & 444.44 & 23 & {$[84]$} \\
\hline Trimethoprim & $\mathrm{C}_{14} \mathrm{H}_{18} \mathrm{~N}_{4} \mathrm{O}_{3}$ & 290.32 & 7700 & {$[84,85]$} \\
\hline \multicolumn{5}{|l|}{ Antimycotics } \\
\hline Fluconazole & $\mathrm{C}_{13} \mathrm{H}_{12} \mathrm{~F}_{2} \mathrm{~N}_{6} \mathrm{O}$ & 306.1 & $3445 \pm 1569$ & {$[87]$} \\
\hline \multicolumn{5}{|l|}{ Antivirals } \\
\hline Oseltamivir & $\mathrm{C}_{16} \mathrm{H}_{31} \mathrm{~N}_{2} \mathrm{O}_{8} \mathrm{P}$ & 410.4 & $25 \pm 18$ & {$[87]$} \\
\hline Ritonavir & $\mathrm{C}_{37} \mathrm{H}_{48} \mathrm{~N}_{6} \mathrm{O}_{5} \mathrm{~S}_{2}$ & 720.9 & $108 \pm 94$ & {$[87]$} \\
\hline \multicolumn{5}{|l|}{ Metabolites } \\
\hline N4-Acetylsulfamethoxazole & $\mathrm{C}_{12} \mathrm{H}_{13} \mathrm{~N}_{3} \mathrm{O}_{4} \mathrm{~S}$ & 295.32 & $2394 \pm 2261$ & [87] \\
\hline Oseltamivir carboxylate & $\mathrm{C}_{14} \mathrm{H}_{24} \mathrm{~N}_{2} \mathrm{O}_{4}$ & 284.35 & $151 \pm 81$ & {$[87]$} \\
\hline
\end{tabular}

\subsection{Radioactive elements and ionic pollutants}

Radioactive elements and some ions are essential resources for hospital treatment and clinical diagnosis [96,97]. For instance, radiotherapy with heavy, charged particles (e.g., protons and carbon ions) is an established treatment option for many tumors [98]. For hospital testing and analysis, elements, and ions, are widely used in hospital imaging, anesthesia, and neuroprotection [6]. However, once these radioactive ions are released through wastewater into the environment, they may pose a high risk to the ecosystem and public health due to their carcinogenic and mutagenic characteristics. Specific ions in discharged hospital wastewater cause severe contamination of drinking water sources [99,100]. Furthermore, there are many valuable and essential ions in the hospital wastewater, which could be selectively separated or extracted for reuse such as Xe [101]. However, the coexistence of chemically similar ions in wastewater severely limits the extraction of these valuable ions [102,103]. Currently, the inevitability of environmental pollution and low-efficiency implementation of the traditional methodologies, including calcina- 
Table 3 Persistent organic compounds found in hospital wastewater

\begin{tabular}{|c|c|c|c|c|}
\hline$\overline{\text { Name }}$ & Chemical formula & $\begin{array}{l}\text { Molecular weight } \\
\quad /\left(\mathrm{g} \cdot \mathrm{mol}^{-1}\right)\end{array}$ & $\begin{array}{c}\text { Concentration upper limit } \\
\qquad /\left(\mu \mathrm{g} \cdot \mathrm{L}^{-1}\right)\end{array}$ & $\overline{\text { Ref. }}$ \\
\hline \multicolumn{5}{|l|}{ Anti-inflammatory preparations } \\
\hline Diclofenac & $\mathrm{C}_{14} \mathrm{H}_{11} \mathrm{Cl}_{2} \mathrm{~N}_{1} \mathrm{O}_{2}$ & 295.0 & $0.833 \pm 0.179$ & [87] \\
\hline Ibuprofen & $\mathrm{C}_{13} \mathrm{H}_{18} \mathrm{O}_{2}$ & 206.3 & 7.8 & [95] \\
\hline Indometacin & $\mathrm{C}_{19} \mathrm{H}_{16} \mathrm{ClNO}_{4}$ & 357.07 & $0.069 \pm 0.080$ & [87] \\
\hline Mefenamic acid & $\mathrm{C}_{15} \mathrm{H}_{15} \mathrm{NO}_{2}$ & 241.2 & $6.140 \pm 1.779$ & [87] \\
\hline Naproxen & $\mathrm{C}_{14} \mathrm{H}_{14} \mathrm{O}_{3}$ & 230.1 & $<5.6$ & [87] \\
\hline Salicylic acid & $\mathrm{C}_{7} \mathrm{H}_{6} \mathrm{O}_{3}$ & 138.1 & 45.3 & [95] \\
\hline \multicolumn{5}{|l|}{ Anti-neoplastics } \\
\hline Cyclophosphamide & $\mathrm{C}_{7} \mathrm{H}_{15} \mathrm{Cl}_{2} \mathrm{~N}_{2} \mathrm{O}_{2} \mathrm{P}$ & 260.0 & $0.161 \pm 0.026$ & [87] \\
\hline Ifosfamide & $\mathrm{C}_{7} \mathrm{H}_{15} \mathrm{Cl}_{2} \mathrm{~N}_{2} \mathrm{O}_{2} \mathrm{P}$ & 260.0 & $0.895 \pm 0.293$ & [87] \\
\hline \multicolumn{5}{|l|}{ Cardiovascular system preparations } \\
\hline Atenolol & $\mathrm{C}_{14} \mathrm{H}_{22} \mathrm{~N}_{2} \mathrm{O}_{3}$ & 266.2 & $2.315 \pm 0.632$ & [87] \\
\hline Atenolol acid (metoprolol acid) & $\mathrm{C}_{14} \mathrm{H}_{21} \mathrm{~N}_{1} \mathrm{O}_{4}$ & 267.1 & $9.840 \pm 1.859$ & [87] \\
\hline Bezafibrate & $\mathrm{C}_{19} \mathrm{H}_{20} \mathrm{ClNO}_{4}$ & 361.1 & $0.063 \pm 0.075$ & [87] \\
\hline Clofibric acid & $\mathrm{C}_{10} \mathrm{H}_{11} \mathrm{ClO}_{3}$ & 214.0 & $<0.07$ & [87] \\
\hline D617 & $\mathrm{C}_{17} \mathrm{H}_{26} \mathrm{~N}_{2} \mathrm{O}_{2}$ & 290.2 & $0.155 \pm 0.114$ & [87] \\
\hline Furosemide & $\mathrm{C}_{12} \mathrm{H}_{11} \mathrm{ClN}_{2} \mathrm{O}_{5} \mathrm{~S}$ & 330.0 & $2.037 \pm 0.595$ & [87] \\
\hline Hydrochlorothiazide & $\mathrm{C}_{7} \mathrm{H}_{8} \mathrm{ClN}_{3} \mathrm{O}_{4} \mathrm{~S}_{2}$ & 297.0 & $1.995 \pm 0.547$ & [87] \\
\hline Metoprolol & $\mathrm{C}_{15} \mathrm{H}_{25} \mathrm{NO}_{3}$ & 267.2 & $1.325 \pm 0.330$ & [87] \\
\hline Propranolol & $\mathrm{C}_{16} \mathrm{H}_{21} \mathrm{NO}_{2}$ & 259.2 & $0.116 \pm 0.041$ & [87] \\
\hline Sotalol & $\mathrm{C}_{12} \mathrm{H}_{20} \mathrm{~N}_{2} \mathrm{O}_{3} \mathrm{~S}$ & 272.1 & $0.700 \pm 0.551$ & [87] \\
\hline Valsartan & $\mathrm{C}_{24} \mathrm{H}_{29} \mathrm{~N}_{5} \mathrm{O}_{3}$ & 435.2 & $3.032 \pm 1.282$ & [87] \\
\hline Verapamil & $\mathrm{C}_{27} \mathrm{H}_{38} \mathrm{~N}_{2} \mathrm{O}_{4}$ & 454.3 & $0.030 \pm 0.022$ & [87] \\
\hline \multicolumn{5}{|l|}{ Hormonal preparations } \\
\hline Bisphenol A & $\mathrm{C}_{15} \mathrm{H}_{16} \mathrm{O}_{2}$ & 228.3 & 0.833 & [84] \\
\hline Dexamethasone & $\mathrm{C}_{22} \mathrm{H}_{29} \mathrm{FO}_{5}$ & 392.2 & $0.147 \pm 0.013$ & [87] \\
\hline $17 \beta$-Estradiol & $\mathrm{C}_{18} \mathrm{H}_{24} \mathrm{O}_{2}$ & 272.4 & 0.030 & [84] \\
\hline Estriol & $\mathrm{C}_{18} \mathrm{H}_{24} \mathrm{O}_{3}$ & 288.4 & 0.092 & [84] \\
\hline Methylprednisolone & $\mathrm{C}_{22} \mathrm{H}_{30} \mathrm{O}_{5}$ & 374.2 & $1.420 \pm 0.768$ & [87] \\
\hline \multicolumn{5}{|l|}{ Nervous system preparations } \\
\hline 4-Acetamidoantipyrine & $\mathrm{C}_{13} \mathrm{H}_{15} \mathrm{~N}_{3} \mathrm{O}_{2}$ & 245.1 & $225 \pm 89$ & [87] \\
\hline 4-Aminoantipyrine & $\mathrm{C}_{11} \mathrm{H}_{13} \mathrm{~N}_{3} \mathrm{O}_{1}$ & 203.1 & $101 \pm 44$ & [87] \\
\hline Carbamazepine & $\mathrm{C}_{15} \mathrm{H}_{12} \mathrm{~N}_{2} \mathrm{O}$ & 236.1 & $0.222 \pm 0.118$ & [87] \\
\hline Diazepam & $\mathrm{C}_{16} \mathrm{H}_{13} \mathrm{ClN}_{2} \mathrm{O}$ & 284.1 & 0.069 & [87] \\
\hline 4-Dimethylaminoantipyrine & $\mathrm{C}_{13} \mathrm{H}_{17} \mathrm{~N}_{3} \mathrm{O}$ & 231.1 & $<0.14$ & [87] \\
\hline Fluoxetine & $\mathrm{C}_{17} \mathrm{H}_{18} \mathrm{~F}_{3} \mathrm{NO}$ & 309.1 & $<0.03$ & [87] \\
\hline Gabapentin & $\mathrm{C}_{9} \mathrm{H}_{17} \mathrm{NO}_{2}$ & 171.1 & $19.40 \pm 24.15$ & [87] \\
\hline 4-Formylaminoantipyrine & $\mathrm{C}_{12} \mathrm{H}_{13} \mathrm{~N}_{3} \mathrm{O}_{2}$ & 231.1 & $47.88 \pm 12.39$ & [87] \\
\hline Levetiracetam & $\mathrm{C}_{8} \mathrm{H}_{14} \mathrm{~N}_{2} \mathrm{O}_{2}$ & 170.1 & $11.02 \pm 6.546$ & [87] \\
\hline Lidocaine & $\mathrm{C}_{14} \mathrm{H}_{22} \mathrm{~N}_{2} \mathrm{O}$ & 234.2 & $9.133 \pm 8.071$ & [87] \\
\hline 4-Methylaminoantipyrine & $\mathrm{C}_{12} \mathrm{H}_{15} \mathrm{~N}_{3} \mathrm{O}$ & 217.1 & $218 \pm 208$ & [87] \\
\hline Morphine & $\mathrm{C}_{17} \mathrm{H}_{19} \mathrm{NO}_{3}$ & 285.1 & $3.679 \pm 1.834$ & [87] \\
\hline Oxazepam & $\mathrm{C}_{15} \mathrm{H}_{11} \mathrm{ClN}_{2} \mathrm{O}_{2}$ & 286.0 & $1.123 \pm 0.335$ & [87] \\
\hline Paracetamol (acetaminophen) & $\mathrm{C}_{8} \mathrm{H}_{9} \mathrm{~N}_{1} \mathrm{O}_{2}$ & 151.1 & $107.0 \pm 85.7$ & [87] \\
\hline
\end{tabular}




\begin{tabular}{|c|c|c|c|c|}
\hline \multicolumn{5}{|c|}{ (Continued) } \\
\hline Name & Chemical formula & $\begin{array}{l}\text { Molecular weight } \\
\quad /\left(\mathrm{g} \cdot \mathrm{mol}^{-1}\right)\end{array}$ & $\begin{array}{c}\text { Concentration upper limit } \\
\qquad /\left(\mu \mathrm{g} \cdot \mathrm{L}^{-1}\right)\end{array}$ & Ref. \\
\hline Phenazone (antipyrine) & $\mathrm{C}_{11} \mathrm{H}_{12} \mathrm{~N}_{2} \mathrm{O}$ & 188.1 & $0.162 \pm 0.079$ & {$[87]$} \\
\hline Primidone & $\mathrm{C}_{12} \mathrm{H}_{14} \mathrm{~N}_{2} \mathrm{O}_{2}$ & 218.1 & $0.383 \pm 0.390$ & [87] \\
\hline Ritalinic acid & $\mathrm{C}_{13} \mathrm{H}_{17} \mathrm{NO}_{2}$ & 219.1 & $0.295 \pm 0.142$ & [87] \\
\hline Thiopental & $\mathrm{C}_{11} \mathrm{H}_{18} \mathrm{~N}_{2} \mathrm{O}_{2} \mathrm{~S}$ & 242.1 & $0.763 \pm 0.860$ & [87] \\
\hline Tramadol & $\mathrm{C}_{16} \mathrm{H}_{25} \mathrm{NO}_{2}$ & 263.2 & $0.958 \pm 0.264$ & [87] \\
\hline Venlafaxine & $\mathrm{C}_{17} \mathrm{H}_{27} \mathrm{NO}_{2}$ & 277.2 & $0.811 \pm 0.316$ & [87] \\
\hline \multicolumn{5}{|l|}{ Other organic compounds } \\
\hline Caffeine & $\mathrm{C}_{8} \mathrm{H}_{10} \mathrm{~N}_{4} \mathrm{O}_{2}$ & 194.2 & 25.8 & [95] \\
\hline Fenofibrate & $\mathrm{C}_{20} \mathrm{H}_{21} \mathrm{ClO}_{4}$ & 360.8 & 0.6 & [95] \\
\hline Gemfibrozil & $\mathrm{C}_{15} \mathrm{H}_{22} \mathrm{O}_{13}$ & 250.3 & 2.7 & [95] \\
\hline \multicolumn{5}{|l|}{ Disinfectant } \\
\hline Triclosan & $\mathrm{C}_{12} \mathrm{H}_{7} \mathrm{Cl}_{3} \mathrm{O}_{2}$ & 289.5 & - & [95] \\
\hline \multicolumn{5}{|l|}{ X-ray contrast media } \\
\hline Diatrizoate (diatrizoic acid) & $\mathrm{C}_{11} \mathrm{H}_{9} \mathrm{I}_{3} \mathrm{~N}_{2} \mathrm{O}_{4}$ & 613.8 & $348.7 \pm 241.0$ & {$[87]$} \\
\hline Iohexol & $\mathrm{C}_{19} \mathrm{H}_{26} \mathrm{I}_{3} \mathrm{~N}_{3} \mathrm{O}_{9}$ & 820.9 & $<12$ & [87] \\
\hline Iomeprol & $\mathrm{C}_{17} \mathrm{H}_{22} \mathrm{I}_{3} \mathrm{~N}_{3} \mathrm{O}_{8}$ & 776.9 & $439.0 \pm 443.9$ & {$[87]$} \\
\hline Iopamidol & $\mathrm{C}_{17} \mathrm{H}_{22} \mathrm{I}_{3} \mathrm{~N}_{3} \mathrm{O}_{8}$ & 776.9 & $2599 \pm 1512$ & [87] \\
\hline Iopromide & $\mathrm{C}_{18} \mathrm{H}_{24} \mathrm{I}_{3} \mathrm{~N}_{3} \mathrm{O}_{8}$ & 790.9 & $170.6 \pm 156.3$ & [87] \\
\hline Ioxitalamic acid & $\mathrm{C}_{12} \mathrm{H}_{11} \mathrm{I}_{3} \mathrm{~N}_{2} \mathrm{O}_{5}$ & 643.8 & $342.0 \pm 197.0$ & [87] \\
\hline
\end{tabular}

tion, adsorption, precipitation, and salting, limit the use of these methods in wastewater treatment [104].

\section{MBR in hospital wastewater treatment}

Conventional MBR is a technology that combines biological treatment with membrane separation. It was first designed and applied in the food industry in the 1970s and then developed to treat various wastewaters during the last few decades [105]. Compared to conventional activated sludge systems, the sedimentation tank is replaced by a membrane process in an MBR. Consequently, numerous advantages, including high effluent quality, low sludge production, and enhanced contaminant removal capacity, are obtained [22]. In theory, MBR is suitable for hospital wastewater treatment: antibiotic groups and organic compounds can be degraded during biological treatment, meanwhile, due to the membrane pores, left pathogenic microorganisms, antibiotic groups, organic compounds, and ionic pollutants are further eliminated [106,107]. To further improve performance in hospital wastewater treatment, the advanced MBRs were developed including that hybridizing some novel membranes into MBR units (defined as hybrid MBRs) or integrating MBR with other membrane processes (defined as integrated MBR-membrane systems).

\subsection{MBR technology}

\subsubsection{Types of membranes used in MBRs}

Membranes are the core part of MBRs and have a critical influence on the rejection of pathogenic microbe and virus in hospital wastewater treatment. During the past 60 years, the rapid development of membrane materials has pushed the evolution of MBR technology from simple and laboratory-scale to complex and large-scale industrial applications. The current MF/UF membranes used in MBRs are made from polymeric, ceramic, and metallic materials (see Table 4).

Polypropylene (PP), polyethylene (PE), polytetrafluoroethylene (PTFE), polyvinylidene difluoride (PVDF), and polysulfone have been widely used in preparing polymeric membranes for MBRs [108]. The polymeric membrane exhibits controllable pore size (distribution), wettability, surface charge, functional groups, and excellent chemical, thermal, mechanical, and hydrolytic stability [109]. Polymeric membrane properties can be modified by polymer selection, polymer blending, and additives addition for different applications [110].

Ceramic membranes are fabricated using $\mathrm{Al}_{2} \mathrm{O}_{3}, \mathrm{TiO}_{2}$, $\mathrm{ZrO}_{2}, \mathrm{SiO}_{2}$ and other inorganic materials. These membranes are reported to have a high chemical, thermal, and mechanical resistance, unique separation properties, and a 
Table 4 Different types of membranes in the MBR process

\begin{tabular}{|c|c|c|c|}
\hline Membrane type & Material & Membrane pore size $/ \mu \mathrm{m}$ & Ref. \\
\hline \multirow[t]{11}{*}{ Polymeric membrane } & PVDF & 0.04 & [118] \\
\hline & PVDF & 0.4 & [119] \\
\hline & PVDF & $<0.1$ & [120] \\
\hline & PVDF & 0.2 & [121] \\
\hline & Polyvinyl chloride & 0.2 & [122] \\
\hline & PTFE & 0.2 & [123] \\
\hline & PE & 0.4 & [124] \\
\hline & $\mathrm{PE}$ & 0.4 & [125] \\
\hline & PE & 0.2 & [126] \\
\hline & High density polyethylene & 0.2 & [127] \\
\hline & PP & 0.03 & [128] \\
\hline \multirow[t]{3}{*}{ Ceramic membrane } & Ceramic & 0.4 & [129] \\
\hline & Silicon carbide & 0.6 & [130] \\
\hline & Ceramic & 0.1 & [131] \\
\hline \multirow[t]{3}{*}{ Metallic membrane } & Flat stainless steel & 0.2 & [113] \\
\hline & Flat stainless steel & 0.2 & [132] \\
\hline & Flat stainless steel & 0.4 & [114] \\
\hline
\end{tabular}

long operational life. They are ideal for treating industrial wastewater and oil-water separation [111]. In the past 20 years, ceramic membranes have been widely studied in MBRs for wastewater treatment [112]. Notably, the placement of ceramic membranes allows the MBRs to operate at high mixed liquid suspended solids concentrations and high fluxes.

Metallic (e.g., Pd, Ag, alloys, and steel) membranes are also used in MBRs because they have a high resistance to extreme acidity or alkalinity, temperature, and highpressure operations. Compare to ceramic membranes, metallic membranes show higher mechanical strength, conductivity and selectivity. Zhang et al. investigated the application of flat stainless steel membranes in aerated submerged MBR for treating synthetic domestic wastewater [113]. The metallic membrane showed a steady permeate flux of $>17 \mathrm{~L} \cdot \mathrm{m}^{-2} \cdot \mathrm{h}^{-1}$ and an average chemical oxygen demand (COD) removal rate of $97 \%$. Xie et al. also used a stainless-steel sheet membrane in MBR for synthetic domestic sewage treatment, which achieved mean removal efficiencies of $96.7 \%$ for COD and $32.1 \%$ for total nitrogen (TN), respectively [114]. Compared with polymeric membranes, ceramic and metallic membranes can be cleaned by high-pressure backwashing, thus reducing the use and impact of cleaning chemicals [115]. However, the main drawback of these membranes is the higher cost, which limits their widespread industrial applications.

Mixed matrix membranes as a novel membrane that hybrid in MBRs have been reported for wastewater treatment. These membranes are the incorporation of synthetic or natural inorganic compounds in a continuous polymer matrix to enhance their chemical and physical properties, including the charge, pore size and distribution, hydrophilicity, and surface roughness [116]. Recently, some highly porous and hydrophilic mixed matrix membranes have been developed and applied in MBRs. For example, Bilad et al. reported a polyvinyl chloride and silica-based mixed matrix membrane with the enhanced porosity, chemical and thermal stability, and used in the MBR [117].

\subsubsection{Bioreactor}

Microorganisms determine the biological treatment in MBRs. Generally, biological processes in MBRs for pharmaceutical removal include biosorption, bioaccumulation, biodegradation, volatilization, and photodegradation [24]. Compared with conventional activated sludge systems, more microorganisms even with a slow growth rate (e.g., nitrifying bacteria) and poor settling performance (e.g., filamentous bacteria) can be retained in the feedstock, and be successfully proliferated in MBR due to membrane rejection, which is beneficial for wastewater treatment $[133,134]$. For certain pollutants in hospital wastewater, the microbial community is mainly controlled by adjusting the ratio of nutrients, controlling dissolved oxygen, dosing chemicals, increasing sludge discharge, and increasing the hydraulic retention time.

\subsection{MBR classification}

\subsubsection{Membrane configuration}

MBRs are classified into submerged MBRs (Fig. 2(a)) and external MBRs (Fig. 2(b)) based on their membrane 
modules inside/outside the bioreactor. In external MBRs, the membrane module and bioreactor are independent, giving easy operation and management advantages. Furthermore, membrane fouling is controlled by using the shearing effect of the high-speed water flow generated by the circulation pump. External MBRs can be worked at constant pressure with different permeate fluxes, while submerged MBRs usually always works at a constant flow with variable transmembrane pressures. However, external MBRs are usually more expensive than submerged MBRs due to their relatively complex operation and maintaining [24].

\subsubsection{Aerobic and anaerobic biological processes}

Conventional MBRs also can be classified as aerobic MBR (Fig. 3(a)) and anaerobic MBR (Fig. 3(b)), depending on whether aeration is used in the bioreactor [136]. Aerobic MBR has been widely used in the treatment of hospital wastewater, landfill leachate, and aquaculture wastewater. Aerobic MBR is easier to operate, but it usually suffers from poor sludge settling, low activated sludge concentration, and low stability under sudden changed wastewater conditions. Compared to aerobic MBR, the anaerobic MBR process has a higher organic load, lower energy consumption, and higher stability to resist the sudden changed wastewater conditions. Besides, anaerobic MBR can be used to recover energy in the form of biogas from wastewater [137]. These attributes make the anaerobic MBR more promising in treating refractory organic wastewater, however, these attributes also make it more difficult to operate than aerobic MBR [138].

\subsection{Hybrid MBRs and integrated MBR-membrane systems}

Currently, increasingly stringent standards and lower-cost processing requirements limit the broad application of MBRs for hospital wastewater treatment. Hence, the hybrid MBRs, which combine the biological treatment with other novel membranes like NF membrane, forward osmotic membrane, and extractive membrane, show high separation efficient for specific inorganic or organic compounds removal. Besides, the integrated MBR-membrane systems, which integrating MBRs and other membrane processes (e.g., RO, NF, and ED), are also promising in hospital wastewater treatment [139]. The following section reviews the application of hybrid MBRs (aeration MBR (AMBR), extractive MBR (EMBR), NF MBR (NMBR) and osmotic MBR (OMBR)) and integrated MBR-membrane systems (integrated MBR-RO process, MBR-NF process, MBR-ED process, and MBRforward osmosis (FO) process).

\subsection{Critical performance indicators of MBRs}

\subsubsection{Solute selectivity}

Some compounds in hospital wastewater, such as waterborne viruses and bacteria, pose a significant threat to humans and require selective separation by the membrane

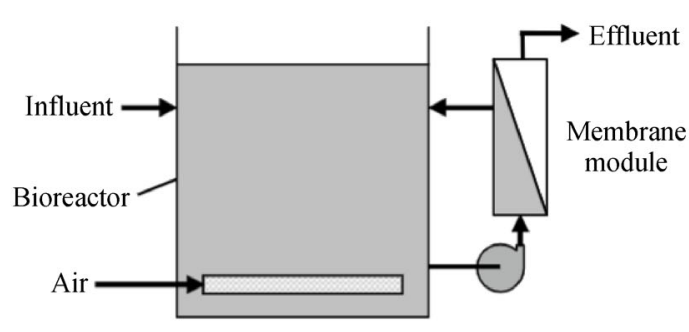

(a)

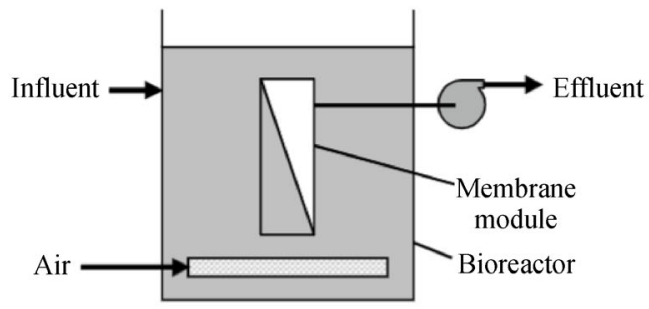

(b)

Fig. 2 (a) External MBR and (b) submerged MBR. Reprinted with permission from ref. [135], copyright 2007, Elsevier.

(a)

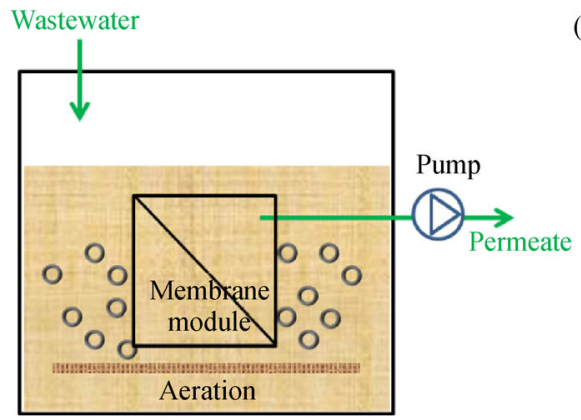

(b)

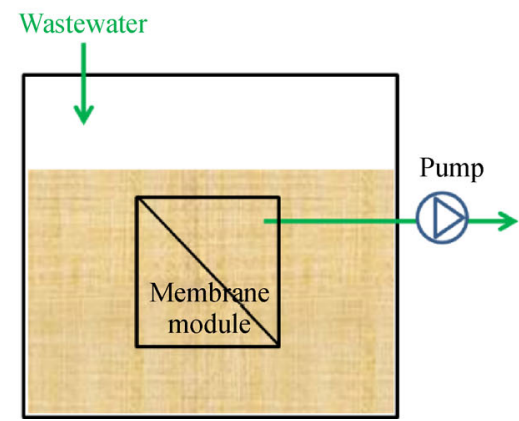

Fig. 3 (a) Aerobic MBR and (b) anaerobic MBR. 
process. Meanwhile, some species such as antivirals, antibacterial, and some radioactive ions may cause serious water pollution when discharged into rivers or lakes. These compounds also require selective separation for removal. Compared with conventional activated sludge systems, membranes used in conventional MBRs exhibit the advantage to achieve a high rejection of suspended solids, macromolecules such as proteins and pathogens, and yield a better effluent quality [140]. However, a low removal rate of pathogenic microbes, ions, and other micromolecules was observed in MF and UF operations due to the large pore sizes [141].

Hybrid MBRs or integrated MBR-membrane systems, such as the RO membranes used in an MBR or a conventional MBR system integrated with NF/ED processes, show a high removal rate or selectivity due to its membrane pore sizes $(<2 \mathrm{~nm})$. The main principle of membrane selectivity in wastewater treatment is the size sieving of the membrane, and membrane electrostatic interaction between membrane and solutes. Size sieving is accomplished through tuning the pore size of the membrane structure. During the separation process for hospital wastewater, molecules larger than the membrane pore size are rejected; otherwise, they will pass through the membranes (Fig. 4(a)).

During hospital wastewater treatment, membrane separation technologies are impeded by a trade-off between flux and retention [142]. To overcome this phenomenon, most membranes are developed using advanced composite materials. For example, many new nanomaterials (from zero-dimensional to three-dimensional) are designed and prepared as membranes with controllable structures (pore size and shape) [143,144]. Nanospheres or nanoparticles have large specific surface areas and are fabricated as functional layers with enhanced membrane flux or selectivity [145-147]. One-dimensional nanomaterials such as nanowires, nanotubes, and nanofibers have high mechanical strength, stability, and selectivity and have been widely used for membrane separation [148-150]. Graphene oxide, MXene, and $\mathrm{MoS}_{2}$ nanosheets are advanced two-dimensional nanomaterials and have nanoscale thickness and controllable interlayer sizes to yield membranes for molecular separations and wastewater treatment [151]. Recently, metal-organic frameworks (MOFs) and covalent organic frameworks based membranes have attracted significant attention for separation processes due to their precisely tunable micro/ mesopores, composition, and functionality $[152,153]$. For example, there are some works on composite NF membranes with controllable structures that use MOFs (such as ZIF-8 and UiO-66- $\mathrm{NH}_{2}$ ) [154-157]. With the development of these novel membranes, hybrid MBRs or integrated MBR-membrane systems have a high potential to remove hazardous compounds or recycle values selectively.

Another effect giving membrane selectivity is the electrostatic interaction (either electrostatic attraction or repulsion), which depends on the interaction force between the charged membrane surface/pores and the target compounds/ions in solution (Fig. 4(b)). During hospital wastewater treatment, membrane surface/pores have opposite charges from target compounds/ions, leading to attractive driving forces for the transport of these materials. Zhang et al. created an artificial solid-state ion pump in the membrane to mimic the delicate ion transport behavior of a biological protein-based ion pump for transport of a target ion from the membrane [158]. Therefore, this membrane type is auspicious for extracting valuable antivirals, antibacterial, other anti-infectives, ions, or elements from hospital wastewater and recycling them for epidemic prevention. Otherwise, when the membrane surface/pores and target compounds/ions show the same charge or repulsive interaction, the retention rate of these target compounds/ions is enhanced. For example, a membrane surface layer constructed by zwitterionic and polycationic components may display high antibacterial properties and rejects viruses and bacteria during hospital wastewater treatment [159]. In this way, by designing the membranes based on the purpose of separation, MBRs can be carefully designed and utilized for simultaneously remove harmful (a)

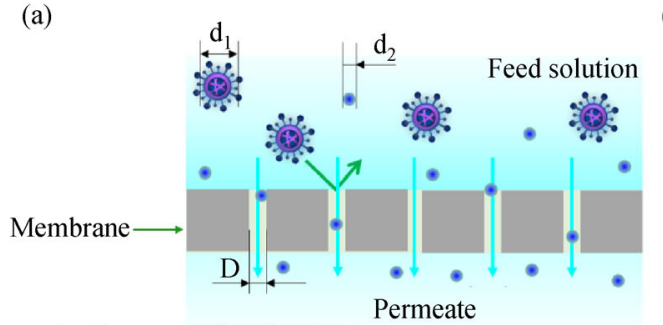

$\mathrm{d}_{\mathrm{i}}$ diameters of molecules

$\mathrm{D}$ membrane pore size

If $\mathrm{d}_{\mathrm{i}}>\mathrm{D}$, the compounds will be rejected;

If $\mathrm{d}_{\mathrm{i}}<\mathrm{D}$, the compounds will pass through the membranes. (b)

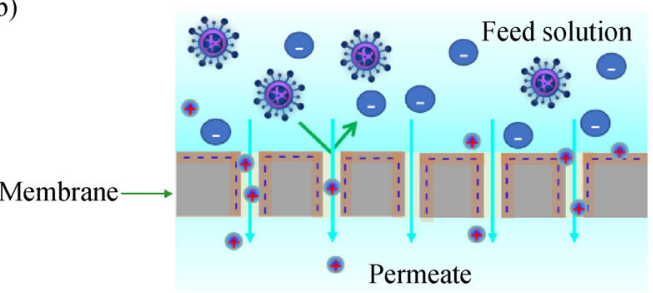

: Big compounds

Electrostatic repulsion of compounds/ions

- Electrostatic attraction of target compounds/ions

Fig. 4 (a) Membrane pore size sieving for different sized compounds/ions; (b) electrostatic interaction for charged compounds/ions. 
materials and extract valuable materials during hospital wastewater treatment.

\subsubsection{Membrane fouling mechanisms in MBR}

Membrane fouling is a significant issue, especially during the separation of hospital wastewater loaded with viruses, bacteria, antivirals, antibacterial, and other compounds. They build-up of cake layers or gel layers and pore blockages, leading to reduced flux or retention rate, and increased energy consumption [160]. Ways to mitigate fouling or reverse flushing are increasing the sludge filterability or physical cleaning during long-term operation. However, sometimes the effects of fouling cannot be reversed (irreversible fouling) [161]. Membrane fouling in MBR processes is classified as biofouling, colloidal fouling, organic fouling, and scaling [162].

Biofouling is caused by bacteria and viruses and leads to the formation and growth of a biofilm. It is considered the most ubiquitous and recalcitrant fouling type. Hospital wastewater contains harmful viruses and bacteria, prompting removal before deposition onto the membrane surface and formation of biofilms [163]. Biofilms form when microorganisms grow on the membrane surfaces [164]. In that context, biofouling during hybrid MBRs or integrated MBR-membrane systems operations may be attributed to the adsorption of organics or toxins generated by microorganisms (Fig. 5(a)). Methods directed at biofouling prevention include feed pretreatment, rinsing or flushing of the membrane surface, and air-sparging and cleaning with different chemical agents [165]. However, these methods have only a temporary effect and cannot prevent membrane biofouling after multiple exposures to pollutants [166]. Antifouling membrane layers have been employed as an efficient method to solve fouling issues. To prevent attachment of these biofouling agents, the membrane surface is usually modified to have high hydrophilicity, low surface roughness, and negative charge, e.g., by incorporating nanomaterials [167-169].

Colloids are non-dissolved suspended solids ranging from $1 \mathrm{~nm}$ to $2 \mu \mathrm{m}$ in size and are abundant in hospital wastewater, including inorganic colloids (such as hydroxides of heavy metals, etc.), organic macromolecules (such as proteins, etc.) and biocolloids (such as viruses and bacteria, etc.) [170]. Colloidal fouling profoundly limits membrane separation performance and may even lead to a complete failure of the membrane separation process [171]. This fouling occurs due to interactive forces between colloidal particles and the membrane surface (Fig. 5(b)) [172,173], including London-van der Waals forces, electrical double layer forces, solvation or hydration forces, hydrophobic forces, and steric forces [174], as described by the Derjaguin, Landau, Verwey, Overbeek theory. Based on this theory, membrane surfaces are usually modified with hydrophilic groups and charged bactericide materials to minimize undesired interactions and prevent or reduce colloidal fouling $[175,176]$.

Organic fouling materials are dissolved into the solution and maintained by covalent bonds, and these bonds lead to interactions with membrane surfaces [177]. These organic foulants originate from large quantities of disinfectant agents, pesticides, organic solvents, alginate, proteins, and other aromatic substances used and discharged into the rivers, leading to a heavy organic matter load in the environment. For instance, a gel layer accumulates in hybrid MBRs or integrated MBR-membrane systems due to continuous organic fouling under sub-critical flux operation $[178,179]$. Especially, humic acids and alginate are significant organic foulants during MBRs operation. These organic substances stick easily to the membrane surface or cause blockages inside to membrane structure during separation (Fig. 5(c)) [180]. The mechanisms of organic fouling are related to the interaction between the organics and membrane surface such as electrostatic and hydrophobic interactions [181].

In hospital wastewater treatment, scaling or inorganic fouling on membranes may occur when ions in wastewater are concentrated and exceed the threshold for solubility of sparingly soluble salts [182], e.g., $\mathrm{Al}^{3+}, \mathrm{Mg}^{2+}, \mathrm{Ca}^{2+}, \mathrm{Ba}^{2+}$, $\mathrm{SO}_{4}{ }^{2-}$ and $\mathrm{CO}_{3}{ }^{2-}$, often exceed the solubilities of sparingly soluble salts. Some metal cations (e.g., $\mathrm{Ca}^{2+}, \mathrm{Mg}^{2+}$ and $\mathrm{Al}^{3+}$ ) react with functional organics groups to form organic-inorganic compounds (Fig. 5(d)) [183]. For example, alginate forms a severe gel layer when $\mathrm{Ca}^{2+}$ is present in wastewater. Inorganic fouling in MBRs processes is due to the precipitation of inorganic crystals on the membrane surface [110]. The metal ions (e.g., $\mathrm{Ca}^{2+}$, $\mathrm{Mg}^{2+}$, and $\mathrm{Al}^{3+}$ ) and some anions (e.g., $\mathrm{OH}^{-}, \mathrm{SO}_{4}{ }^{2-}$ and $\mathrm{CO}_{3}{ }^{2-}$ ) react and lead to chemical precipitation on the membrane surface [177]. Likewise, scaling occurs when saturation concentrations of some insoluble salts $\left(\mathrm{CaSO}_{4}\right)$ are exceeded in the concentrate solution. Inorganic crystals existing in the MBRs processes may accumulate in the membrane channels and then block membrane pores. Conventionally, two main factors affecting the scaling formation on membrane surfaces; one is the characteristics of the filtered solution (including concentration of ions, $\mathrm{pH}$ of solutions and temperature of solutions), and the other is the characteristics of the membrane (including membrane structure, and the charge of the membrane surface) [182].

\section{MBR advancements for potential hospital wastewater treatment}

\subsection{Hybrid MBRs}

As analyzed in Section 3.4.2, the hydrophilic UF/MF membranes commonly employed in the conventional MBR units are subject to severe fouling and hence rapid 


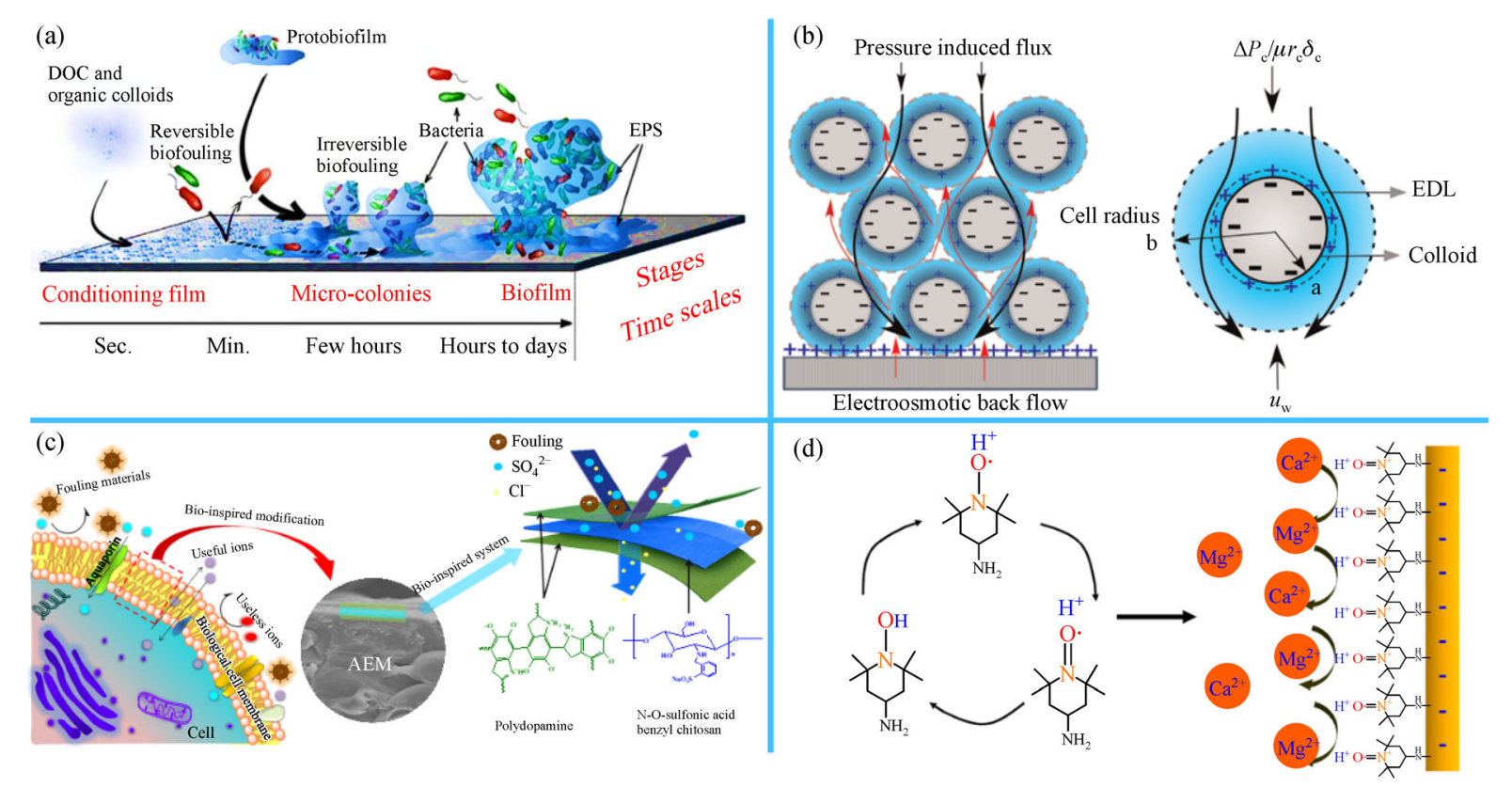

Fig. 5 The mechanism of four main fouling types in membrane processes used in wastewater treatment. (a) Biofouling by bacteria, viruses, the formation, and growth of biofilm. Reprinted with permission from ref. [165], copyright 2017, Elsevier. (b) Colloidal fouling mechanism. Reprinted with permission from ref. [172], copyright 2015, Elsevier. (c) Organic fouling. Reprinted with permission from ref. [180], copyright 2016, Springer Nature. (d) Scaling resistance. Reprinted with permission from ref. [183], copyright 2021, Elsevier.

flux decline. In recent years, there is a surge of interest to adapt the use of MBRs for achieving various separation purposes, depending on the main aim of purification, e.g., volatile removal, extraction of valuable components. Thus, novel concepts of hybrid MBRs have evolved by employing other types of membranes such as hydrophobic or nonUF/MF membranes. In this part, the use of hybrid MBRs in hospital wastewater treatment, including AMBR, EMBR, NMBR, OMBR and ED MBR (EDMBR) are reviewed.

\subsubsection{AMBR}

In AMBR, a dense permeable membrane or a microporous membrane with high hydrophobicity is used for aeration rather than wastewater separation and thus adopted in volatile removal, which exhibits a larger membrane surface and oxygen transfer area than the previous aeration method (Fig. 6). In AMBR, $\mathrm{O}_{2}$ could be supplied directly to the biofilm on membrane surface, and bubble-free air improves the aeration efficiency. These characteristics make AMBR more suitable for treating wastewater containing volatile organic compounds such as xylene, acetonitrile, and perchloroethylene. In this way, no bubbles are generated during reactor operation, reducing the pollution generated by volatile organics. $\mathrm{Li}$ et al. reported that the AMBR was applied in the treatment of acetonitrile wastewater, and the removal rates of total organic carbon and TN approached $98.6 \%$ and $83.3 \%$, respectively [184]. Furthermore, Tian et al. demonstrated the high efficiency for $o$-aminophenol removal by applying a two-stage AMBR process [185], which confirmed the advantages of AMBR in removing COD, biochemical oxygen demand, turbidity, $\mathrm{NH}_{4}{ }^{+}-\mathrm{N}$, and TN.

\subsubsection{EMBR}

EMBR is a novel membrane-based process, which employs a selectively permeable membrane (usually hydrophobic-organophilic membrane) to replace the $\mathrm{MF} /$ UF membrane in conventional MBR [187]. In EMBR, the membrane has tailored pore structure to selectively separate the targeted organic compounds from inorganic compounds, rather than acting as a physical barrier to separate wastewater from microorganisms. Inorganic compounds (salts, metals, charges ions) are rejected by the membrane, freeing microorganisms from underlying inhibitory effects with high bioactivity [188]. Thus, the toxic organic compounds in wastewater are permeated into the bioreactor and subsequently biodegraded by microorganisms [189]. Ongoing biodegradation is helpful to maintain the concentration gradient between membrane sides. Thus the continuous separation and biodegradation of targeted organic compounds is achieved [190]. EMBR exhibits several advantages during the treatment of wastewaters: no need for high pressure in conventional MBR and pre-treatment, low secondary waste stream production (less than 1\%), low demands for post-treatment and waste disposal, and low operational cost [191]. 


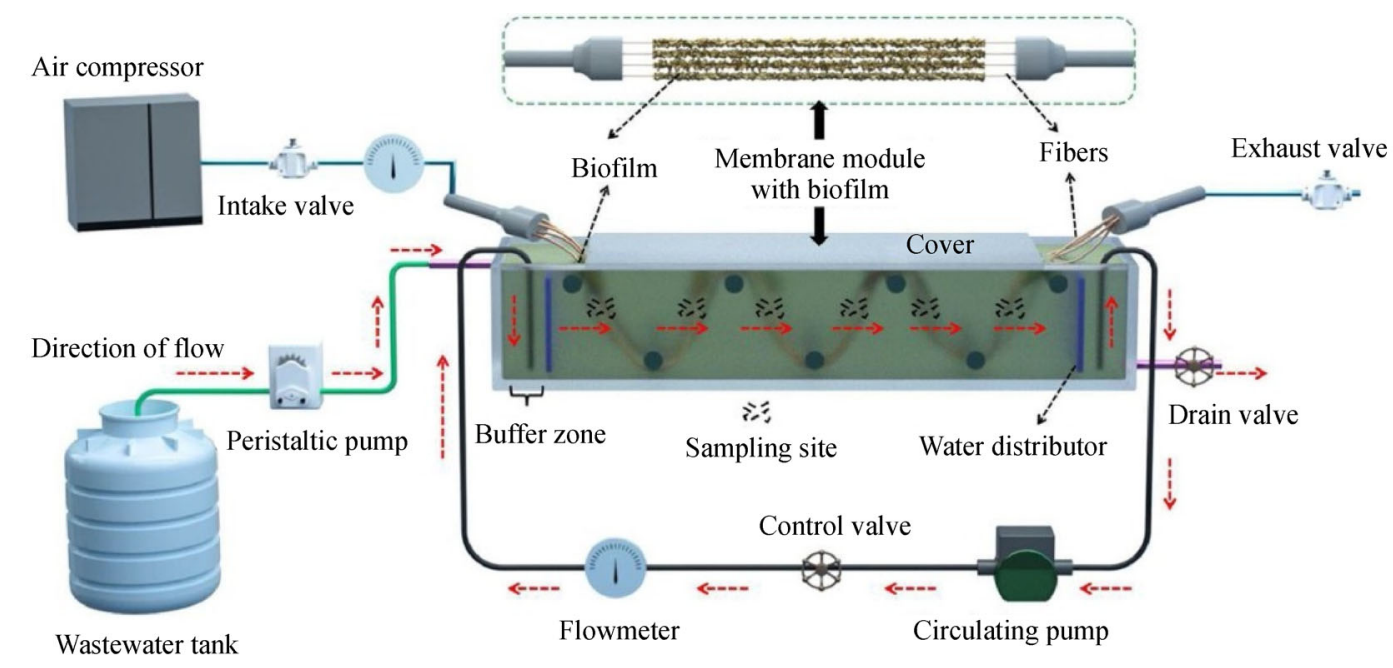

Fig. 6 Schematic diagram of AMBR system. Reprinted with permission from ref. [186], copyright 2020, Elsevier.

Commercial non-porous polydimethylsiloxane (PDMS) tubular membranes [192,193] were initially used in EMBRs. An EMBR using silicone rubber tube membrane (non-porous PDMS) was designed by Xiao et al., and found to be effective in treating phenol saline wastewater $\left(5000-5500 \mathrm{mg} \cdot \mathrm{L}^{-1}\right.$ phenol, $\left.25-300 \mathrm{~g} \cdot \mathrm{L}^{-1} \mathrm{NaCl}\right)$ with a phenol removal efficiency above $95 \%$ under optimized conditions [194]. Afterwards, specifically designed nonporous PDMS flat-sheet membranes $[195,196]$ and nonporous thin PDMS flat-sheet membranes with porous support $[197,198]$ were developed to improve the separation efficiency of organic compounds. Liao et al. employed a dry phase inversion method to coat the thin film PDMS layer (with the thickness range of 3-22 $\mu \mathrm{m}$ ) on the top of an electrospun layer (Fig. 7) [197]. Compared with nonporous PDMS tubular membranes, the thickness of the non-porous PDMS layer on a substrate was decreased significantly, and resultant phenol mass transfer coefficients significantly increased to $4.1-6.5 \mathrm{~m} \cdot \mathrm{s}^{-1}[197,198]$. These findings make EMBR suitable to treat inorganicorganic composite wastewater [199-201].

\subsubsection{NMBR}

Compared with conventional MBR with UF/MF membranes, MBR with NMBR (Fig. 8) can further improve solute rejection and enhance the quality of produced water. NF membranes effectively retain organic contaminants with low molecular weight, increase the bioreactor retention time, and achieve better biodegradation [202]. They also effectively reject the hydrophilic and/or charged antibiotic groups and organic compounds (molecule weight $>200 \mathrm{Da}$ ) via membrane adsorption, size exclusion, and electrostatic exclusion [203]. The permeate flux of conventional MBR is usually in the range of 10 $150 \mathrm{~L} \cdot \mathrm{m}^{-2} \cdot \mathrm{h}^{-1}$, depending on operating pressures and

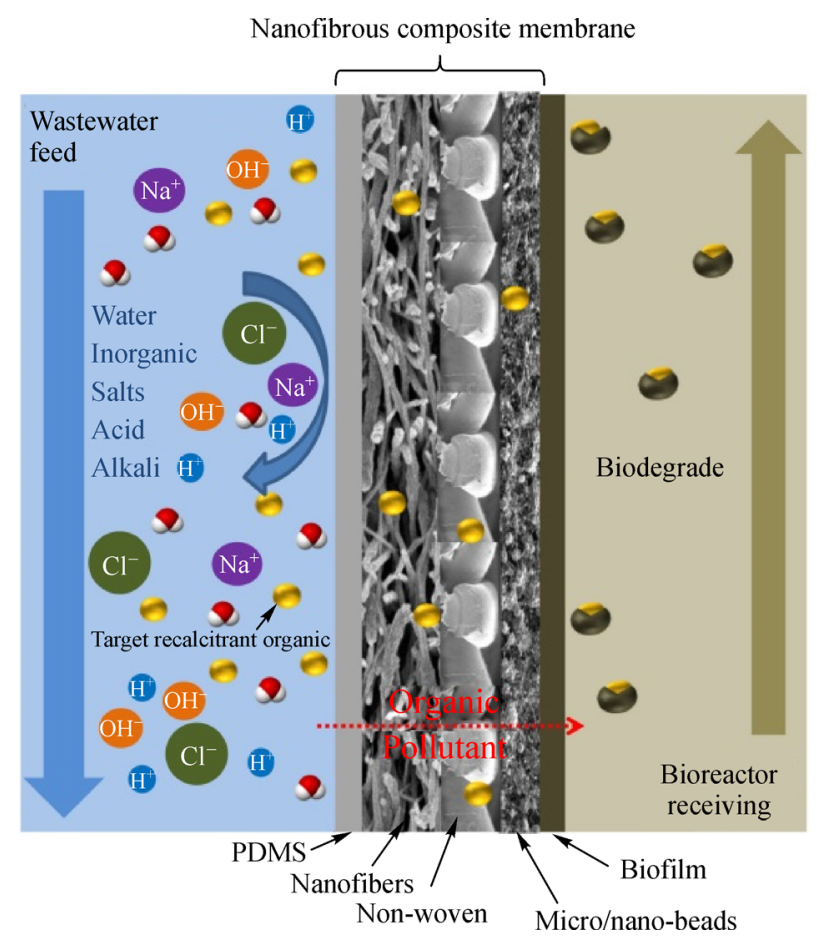

Fig. 7 Schematic diagram of EMBR system. Reprinted with permission from ref. [197], copyright 2018, Elsevier.

membrane structures [202]. In comparison, the permeate flux of NMBR is relatively lower. A submerged MBR using cellulose acetate NF membrane was developed by Choi et al. to treat domestic wastewater [204]. Results showed that dissolved organic carbon concentration in the effluent was $0.5-2.0 \mathrm{mg} \cdot \mathrm{L}^{-1}$, and salt rejections $\left(\mathrm{Cl}^{-}, \mathrm{Na}^{+}\right.$, $\mathrm{SO}_{2}^{-}$and $\mathrm{Ca}^{2+}$ ) were between $40 \%-90 \%$ during operation. Zaviska et al. also investigated an MBR system using ceramic NF multitubular membrane to treat antibiotic groups (cyclophosphamide and ciprofloxacin) [205]. This 


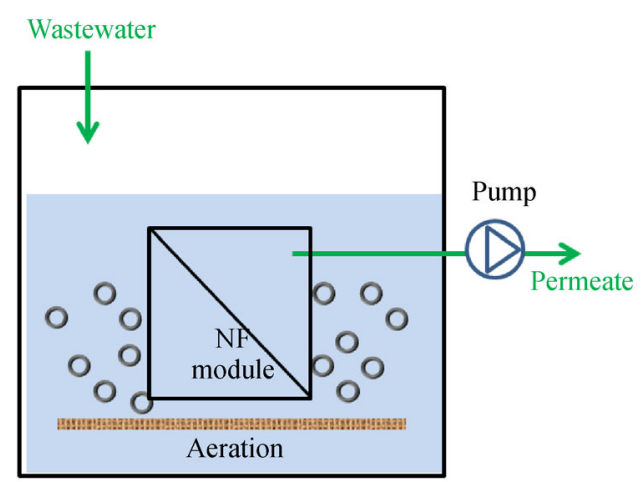

Fig. 8 Schematic diagram of NMBR system.

ceramic membrane further retained antibiotic groups and accumulated them in a bioreactor. Consequently, high remove efficiencies of COD, total suspended solids, and color were observed.

In addition to the low water permeate flux, the membrane biofouling is another limitation of NMBR. To alleviate membrane fouling in NMBR, a high cross-flow velocity and suitable permeate recovery are usually used to minimize the cake layer formation on the membrane surface. Besides, it is essential to develop a novel NF membrane with high fouling resistance, chemical stability, and water permeates flux [206].

Depending on whether aeration is used in MBR system, NMBR can be classified as aerobic NMBR and anaerobic NMBR. The aerobic NMBR is equipped with bio-carriers, and the dissolved oxygen is maintained by aeration rate. An air pump is used to aerate NMBR system for biological growth and provide a constant air flow rate to reduce fouling. Aerobic NMBR process presents excellent biodegradation efficiency and organic removal. Ming et al. reported a high organic removal $(>97 \%)$ and ammonia removal $(>98 \%)$ for the treatment of municipal wastewater via aerobic NMBR [207]. The anaerobic NMBR can be used to prepare chemicals such as glycerol through fermentation, and NF membrane played an important role in nutrition rejection [208]. Especially, the external anaerobic NMBR system was proposed by Snowdon et al., which the high-strength starch-based wastewater was treated by anaerobic MBR system, then NF membranes were applied to treat the anaerobic MBR effluent [209]. Compare to aerobic NMBR, the anaerobic NMBR can decrease operation costs and sludge yields.

\subsubsection{OMBR}

OMBR is a relatively new concept that was first proposed in 2008 by combining the MBR and FO processes, as shown in Fig. 9, which simultaneously achieves the organic compounds removal by biological treatment and physicochemical separation of produced water by $\mathrm{FO}$ [210,211]. Compared to conventional MBR with MF/UF membranes, produced water in OMBR can spontaneously pass through the FO membrane driven by the osmotic pressure difference [212]. The OMBR has several advantages, including high produced water quality, low membrane fouling tendency, and potentially low energy demands $[213,214]$. An OMBR system was set up by Lay et al. using cellulose triacetate membrane to investigate its performance in the removal of pharmaceuticals from wastewater, and the results showed that removal efficiencies of carbamazepine, diclofenac and ibuprofen were above $96 \%$ with a stable water flux of $2.7 \mathrm{~L} \cdot \mathrm{m}^{-2} \cdot \mathrm{h}^{-1}$ [215]. Alturki et al. further demonstrated the performance of OMBR for the removal of 50 trace organic compounds [216]. For trace organic compounds with molar weight

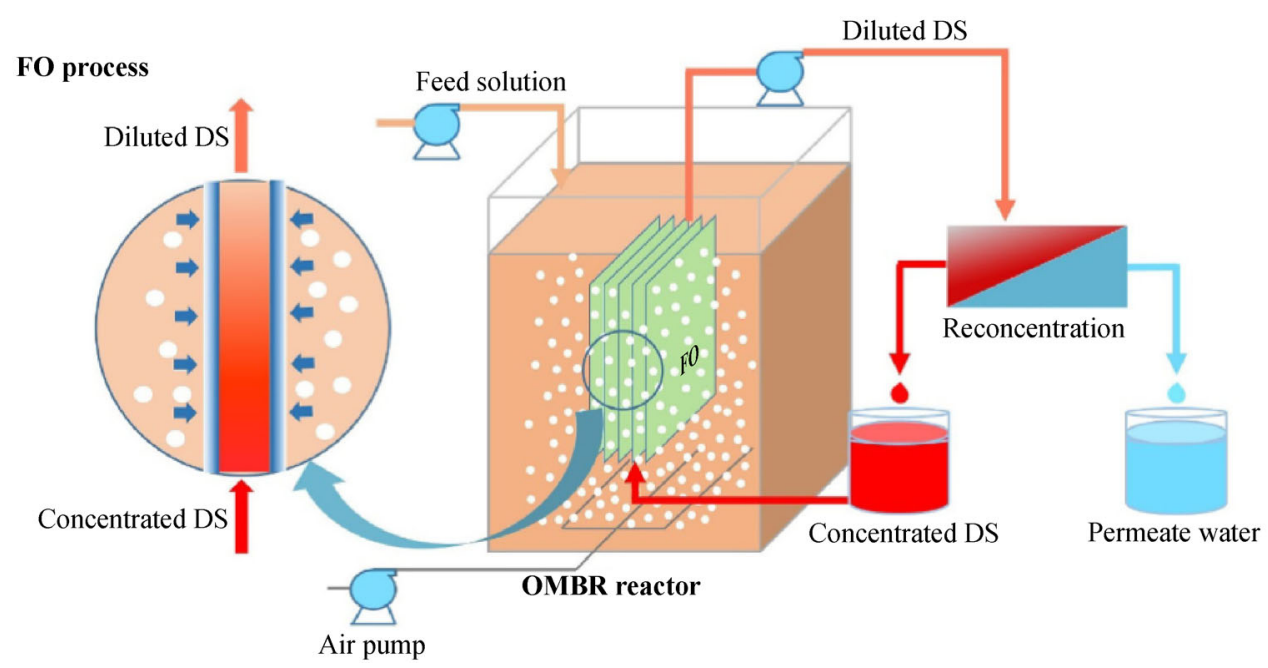

Fig. 9 Schematic diagram of OMBR system integrated with an ED unit to regenerate the draw solution. Reprinted with permission from ref. [220], copyright 2019, Elsevier. 
above $266 \mathrm{Da}$, the obtained removal efficiencies were above $80 \%$, while for a molar weight below $266 \mathrm{Da}$, the removal efficiencies were scattered.

The draw solution is another crucial factor in OMBR. The most widely used draw solution is an inorganic salt solution (especially $\mathrm{NaCl}$ solution) [217]. Salt concentrations gradually increase in the bioreactor during OMBR operation, which reduces the effective draw from the bioreactor to the draw solution, affects microorganism bioactivity, and inhibits biological treatment efficiency [213]. Simultaneously, the elevated salt concentration promotes the release of soluble microbial products and extracellular polymers in the bioreactor, which aggravates the membrane fouling in OMBR [218]. Besides, the main inherent problem of OMBR for hospital wastewater treatment is the inevitable dilution of the draw solution resulting in reduced process driving force. Thus, other membrane separation processes (NF, RO) are needed to reconcentrate and replenish the draw solution. For example, $\mathrm{Lu}$ and $\mathrm{He}$ studied a system incorporating OMBR and ED process for wastewater treatment and waste salt recovery [219]. Results indicated that the hybrid OMBR-ED system could achieve a stable water flux of about $6.23 \mathrm{~L} \cdot \mathrm{m}^{-2} \cdot \mathrm{h}^{-1}$ and salt recovery of $1.26 \mathrm{~kg} \cdot \mathrm{m}^{-3}$. Figure 9 showed a diagram of OMBR system integrated with an ED unit to regenerate the draw solution [220].

\subsubsection{EDMBR}

EDMBR is a novel reactor that integrates ED into the MBR process. Geng et al. used EDMBR for enhanced biological phosphorus removal (EBPR) sludge treatment for the recovery of energy and phosphorus resource [221]. Results indicated that over $90 \%$ of the phosphorus in the EBPR sludge is released, while about $50 \%$ of the phosphorus is concentrated to $4 \mathrm{mmol} \cdot \mathrm{L}^{-1}$ as a relatively pure phosphate solution. Nitrogen can be removed from EBPR sludge by desalination and denitrification processes. Wang et al. developed a novel ion selective EDMBR for sourceseparated urine treatment and resource recovery by integrating selective ED into the EMBR [222]. Results showed that $97.4 \%$ of the $\mathrm{NH}_{4}{ }^{+}, 76.7 \%$ of the $\mathrm{PO}_{4}{ }^{3-}$, and $94.5 \%$ of the $\mathrm{SO}_{4}{ }^{2-}$ was removed, while $65 \%$ of the phosphate and $54.9 \%$ of the sulfate (based on their amounts in urine after stripping) were recovered as a concentrated solution. The minerals in the wastewater stream (e.g., $\mathrm{NaCl}$ ) were selectively retained as brine.

\subsection{Integrated MBR-membrane systems}

The following sections review the integrated MBRmembrane systems, where MBR is used as a pretreatment step and other membrane processes are used for the subsequent purification. Such integrated systems provide clear advantages toward an efficient wastewater treatment, such as high operational flexibility, stability, and treatment versatility. Also, it may help to reduce the membrane fouling issues compared to what was observed in the hybrid units (as discussed in Section 4.1).

\subsubsection{Integrated MBR-RO system}

Integrated MBR-RO systems combine an MBR treatment system with a high-pressure RO membrane treatment system. The MBR serves as a pretreatment process to remove large solids and organic matter from the wastewater. Then, the RO process removes the remaining contaminants, including more than $90 \%$ of monovalent ions, $95 \%$ of divalent ions, and nutrient ions. Compared to NF, UF, and MF membranes, RO membranes offer much higher rejection and thus their integration with MBR demonstrated great potential in water purification and reuse. The other main advantages for integrated MBR-RO systems are the greater removal efficiency of pharmaceuticals and endocrine-disrupting chemicals [84,223-226]. In 2010, Beier et al. created the first full-scale integrated MBR-RO system for hospital wastewater treatment and effectively removed all pharmaceutical residues [227]. Since then, other researchers have built and tested MBRRO systems to remove contaminants including viruses, bacteria, pharmaceuticals, and organic compounds from wastewater sources in municipal and domestic sewage WWTPs, where hospital wastewater is normally directed toward.

The removal of viruses, bacteria, and pathogens is essential in treating hospital wastewater for reuse applications and avoiding reinfection. Several studies used an integrated MBR-RO system to filter various pathogens from municipal wastewater and sewage. For example, Tam et al. investigated the feasibility of an MBR-RO system to reclaim treated effluent for potable and non-potable reuse applications [228]. Their MBR unit removed organic matter and nitrogen to an acceptable level. Then, RO membrane filtration improved the treated water quality in terms of turbidity, organic content, ammonia, nitrate, hardness, and Escherichia coli and virus requirements. Comerton et al. developed an integrated MBR-RO system to filter water-borne pathogens, disinfection byproducts, and nitrate from municipal wastewater. They found the filtered water was suitable for non-potable use and passed the California Title 22 reuse regulation and US EPA drinking eater limits for viruses and chlorite $\left(1.0 \mathrm{mg} \cdot \mathrm{L}^{-1}\right)$ [229]. Prado et al. compared the virus removal efficiency from WWTPs by tertiary or advanced sewage treatment processes, such as sedimentation, sand-anthracite filters, MBR-RO system, and disinfection by chlorination. They found the highest virus removal for MBR-RO system approached $2.9 \log 10$ [230]. In another study, this group found MBR-RO system completely removed noroviruses from WWTPs and are more suitable for applications 
requiring high-quality produced water [231]. Plevri et al. reported a compact MBR-RO system and sewer mining technique with a treatment capacity greater than the total consumption for 100000 population equivalents. Sewer mining is the direct treatment of raw wastewater from the sewage network, on-site treatment, and immediate water reuse. Their system achieved water quality with no $E$. coli detectable and heavy metals to concentrations below the detection limit, and thus meeting the Greek legislative requirements [232,233].

Antibiotics groups, pharmaceuticals, and other organic compounds are another category of hospital wastewater contaminant [234]. Several studies explored the removal of these contaminants from municipal and industrial wastewater in the past six years. Li et al. published a review detailing the applications of MBR-RO system in pharmaceutical micropollutant removal before 2015 [234-236]. While the recent advancement in the past six years have not been reviewed. Racar et al. investigated the feasibility of the raw municipal wastewater reclamation by an integrated MBR-NF/RO system. The MBRs achieved a high removal efficiency of methiocarb $(>99.9 \%)$, triallate $(>99.9 \%)$, clothianidin $(>88.0 \%)$, and clarithromycin (71.9\%-74.2\%). Further treatment with RO XLE (a commercial RO membrane, Dow FilmTec., USA.) and NF90 membranes showed very high removal rates (>99\%) for all compounds [224]. Wang et al. applied MBR-RO system to achieve a deep removal of pharmaceuticals and personal care products (PPCPs) in municipal wastewater. The results showed that the removal rate of PPCPs by the traditional MBR system ranged from $41.08 \%$ to $95.41 \%$; while the removal rate of most PPCPs by integrated MBRRO/NF system could reach more than 95\% [84]. Mamo et al. also achieved over $99 \%$ removal of 13 pharmaceuticals, 20 metabolites, and transformation products using an MBR-RO system at a permeate flux of $18 \mathrm{~L} \cdot \mathrm{m}^{-2} \cdot \mathrm{h}^{-1}$ [223]. Aziz and Ojumu treated domestic wastewater using an MBR-RO system to remove natural steroid hormones $17 \beta$ estradiol and testosterone, and they found excellent removal rates $>95 \%$ for both compounds [237].

However, the emergence of membrane fouling is still an inevitable problem. Díaz et al. found that organic fouling, mainly polysaccharides and proteins, is the predominant issue when using RO as a secondary step after the MBR pretreatment. Also, inorganic foulants consisted of calcium, phosphorus, and iron [225]. Wu et al. observed the membrane fouling propensities of RO membranes in two parallel MBR-RO systems with varying food to microorganism (F/M) ratios (Fig. 10). The results show that more organic matter in the high $\mathrm{F} / \mathrm{M}\left(0.50 \mathrm{~g} \cdot \mathrm{g}^{-1} \cdot \mathrm{d}^{-1}\right) \mathrm{MBR}$ permeate led to higher $\mathrm{RO}$ scaling rates $(>4.5$-fold) compared to the low $\mathrm{F} / \mathrm{M}\left(0.17 \mathrm{~g} \cdot \mathrm{g}^{-1} \cdot \mathrm{d}^{-1}\right)$ MBR scenario [238].

Overall, integrated MBR-RO systems have demonstrated to be the most effective in treating pathogens, pharmaceuticals, and other organic compounds from hospital and municipal WWTPs. But fouling and high energy requirements remain significant limitations to this technology. While there is much evidence that MBR-RO systems can thoroughly disinfect wastewater, it is still

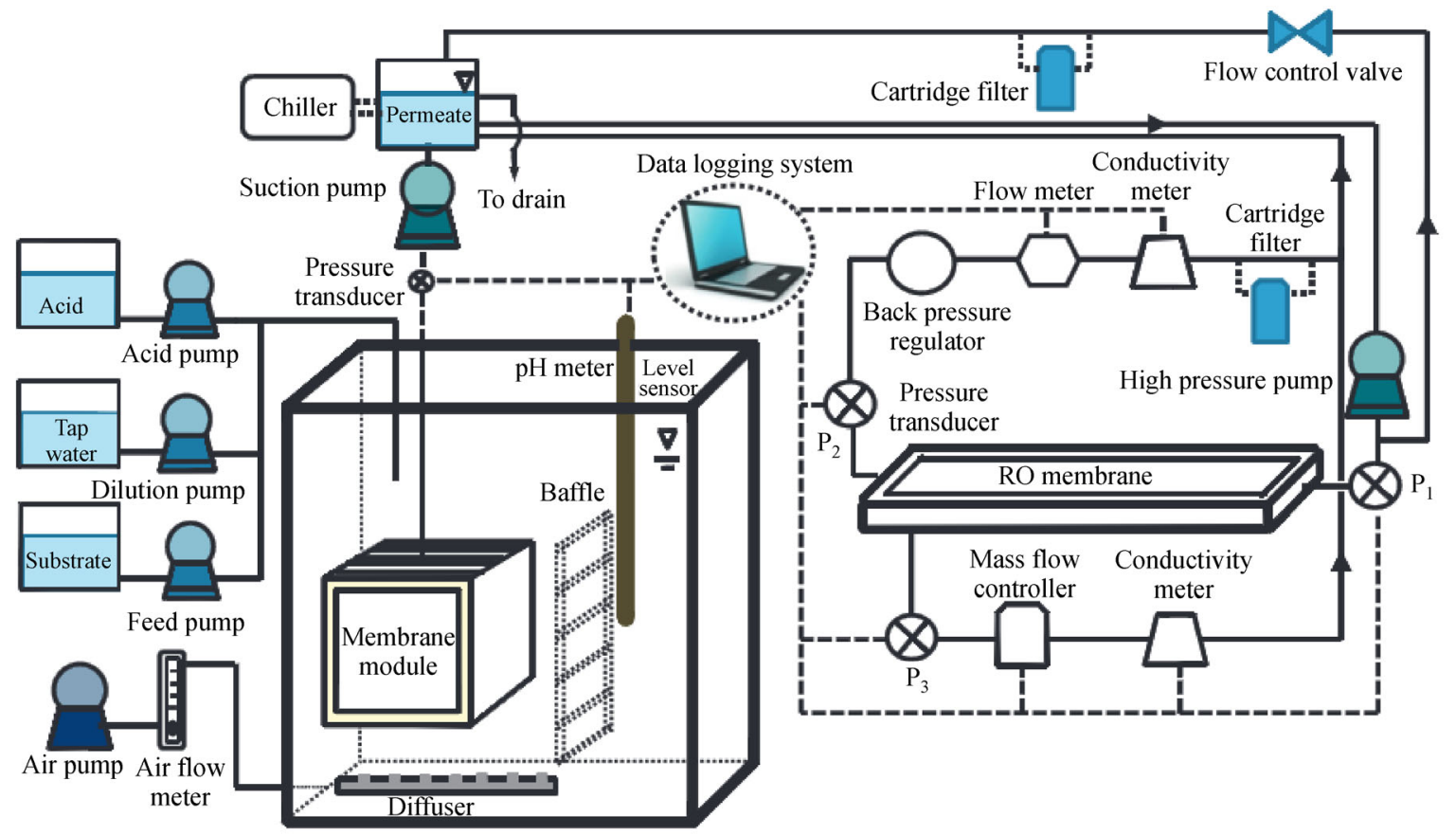

Fig. 10 The scheme of integrated MBR-RO systems. Reprinted with permission from ref. [238], copyright 2013, Elsevier. 
recommended to include an additional filtration step for high-quality water and drinking water applications.

\subsubsection{Integrated MBR-NF system}

Integrated MBR-NF systems combine a MBR treatment system with a high-pressure NF membrane treatment system. In this case, the MBR serves as a pretreatment system and limits the number of biodegradable compounds and organic matter in the hospital wastewater for the subsequent NF treatment. The effectiveness of the MBRNF system has been studied extensively for treating municipal landfill leachate, saltwater and brackish water for desalination, and industrial and pharmaceutical wastewater [239-242]. Recently, researchers have explored MBR-NF systems for hospital wastewater because MBRs alone are insufficient at removing all pharmaceuticals, disinfectants, metabolites, and particularly iodinated contrast media (Fig. 11) [87]. Therefore, an additional NF filtration acts the purification step to remove bio-refractory micropollutants, hardness salts, and heavy metals from hospital wastewater thoroughly and enable its sustainable reuse and recycling.

There are several advantages to treating hospital wastewater with intreated MBR and NF treatment systems, as the synergy promotes the treatment efficiency. First, compared to using an NF system alone, an MBR pretreatment step significantly improves an integrated NF treatment system's efficiency and stability/lifespan [243]. Second, based on the application, NF membrane treatment is preferable to other integrated MBR-membrane treatment systems. For water softening applications, NF systems allow the passage of monovalent ions and retain multivalent ions. NF membranes are also very effective at bacteria elimination, pharmaceuticals, personal care products, and organic compound removal [84,244]. Moreover, NF membranes have smaller pore sizes (1-2 nm) than UF and MF membranes to reject smaller viruses and maintain microbial quality in wastewater systems for high residence time. Compared to RO, NF systems use lower operating pressures, have higher fluxes, and lower implementation and operation costs [226]. However, MBR-NF systems are not able to produce high quality water, i.e., drinking water, which is only possible when coupled with additional posttreatment steps for complete disinfection or desalination.

Despite these advantages, fouling and irreversible membrane scaling remain a significant disadvantage of MBR-NF systems, limiting their greater implementation for hospital wastewater treatment. Fouling occurs when colloidal-sized substances and soluble inorganic compounds such as silica, metal oxides, and microorganisms pass through the MBR and deposit and stick onto the NF membrane surface, leading to a decline in flux, increased energy demand and operation costs, and conception of cleaning chemicals.
To create a fouling and scaling control strategy for MBR-NF systems, Lan et al. conducted a study to optimize the permeate flux using wastewater from Purpan, a hospital in Toulouse, France, and found critical flux, threshold flux, and limiting flux [245]. The critical flux is the flux below which no fouling occurs and permeate drag forces overcome repulsive membrane forces, inducing foulant deposition on the membrane surface. The threshold flux is the flux below which a low constant fouling rate occurs; while above it, the fouling rate increases rapidly. The limiting flux represents the maximum stationary flux at a transmembrane pressure with a given solution, and above it, an increase in transmembrane pressure does not increase flux. The corresponding values for these fluxes were $70 \mathrm{~L} \cdot \mathrm{h}^{-1} \cdot \mathrm{m}^{-2}$ at $3.4 \mathrm{bar}$ and $33 \mathrm{~L} \cdot \mathrm{h}^{-1} \cdot \mathrm{m}^{-2}$ for the limiting flux at 10-35 bar. The exact threshold flux was not found but occurred around 3.4 to 10 bar. By optimizing these parameters, they could correlate flux behavior and fouling mechanisms for MBR-NF systems.

However, these correlated mechanisms are highly susceptible to the MBR efficiency and effluent composition. Therefore, Lan et al. proposed a follow-up study to correlate fouling mechanisms and foulant compositions in an MBR-NF medical wastewater treatment system [246]. They used the same MBR effluent and NF membrane system from the previous study and altered the transmembrane pressures to find a stable flux filtration [245]. Then, they used surface morphology and chemical composition analysis to establish a quantitative link between stable flux and calcium phosphate concentration in MBR effluents and found a specific range of $\mathrm{pH}$ values reasonable for the irreversible fouling of calcium phosphate on the NF membrane.

Despite the fouling issue, other studies have shown excellent separation performance for integrated MBR-NF systems. In a study by Tran et al., an integrated MBR-NF system was evaluated for treating medical wastewater from the Military hospital 175 in Ho Chi Minh City, Vietnam. For organic loading rates of $2.5 \mathrm{~kg} C O D \mathrm{~m}^{-3} \cdot \mathrm{d}^{-1}$, the performance of the integrated system showed a consistently high COD removal average of $92.7 \%$, nitrogen removal rate of $83 \%, \log$ removal rate for $E$. coli, and coliform bacteria four times higher than the average. Overall, this integrated system produced grade A effluent according to the Vietnamese water quality standards. Likewise, Beier et al. confirmed using MBR technology followed by an advanced NF post-treatment step [227]. They used wastewater from Waldbröl hospital in Germany and achieved excellent performance for separating compounds with a molar weight greater than $200 \mathrm{~g} \cdot \mathrm{mol}^{-1}$. Besides these studies on hospital wastewater, several other MBR-NF systems have been used to purify wastewater from pharmaceutical industry containing trace organic compounds, antibiotic groups, and other micropollutants [223,224,240,247-249].

Overall, the MBR-NF systems have demonstrated 
potential in treating hospital wastewater on-site to prevent the pollution of aquatic ecosystems and offer many advantages compared to other integrated systems. Significant progress has been made on fouling control strategies. Nevertheless, MBR-NF systems are less effective in solute rejection and should only be used in applications with lower water quality.

\section{Conclusions and outlook}

Given the rapid spread of emerging infectious diseases during the global epidemics, urgent preventative actions should be taken. During epidemic treatment, large amounts of hospital wastewater from hospitals and related medical activities are discharged into our waterways, posing high risks to human health and may contribute to the failure in pandemic control. Meanwhile, despite the growing concern over the hospital waste management, there is still a lack of attention on treatment technologies for hospital wastewater.

Membrane technology possesses distinct advantages in achieving selective separation, significantly less chemical consumption, less byproducts as secondary pollutants, and higher energy efficiency. Based on current advancement in membrane technology for hospital wastewater treatment, the future trends of their applications are discussed as follows:

1) By applying MBRs, pharmaceuticals can be effectively removed from hospital wastewater via the integration biodegradation/adsorption and membrane filtration. Other than conventional UF/MF hydrophilic membranes, the evolution of novel MBR concepts is emerging by employing other types of membranes to achieve different separation purposes, such as volatile removal, selective extraction of particular microorganisms of interests. The tailoring of high-performance membranes for the MBR applications has created new research avenue, including the incorporation of functional materials such as nanoparticles to enhance selectivity and permeability, and reduce fouling.

2) MBRs play an essential role in removing viruses from hospital wastewater in large-scale WWTPs. However, the different removal efficiencies of the same virus through different types of MBRs are not compared or rationalized; the reasons for the widely scattering data (of removal efficiency) for different virus is not well understood. Therefore, more investigation is still required to processing viral pathogens with the different capabilities of MBRs.

3) The mitigation strategies to reduce irreversible membrane fouling need to be further investigated. Further control strategies such as the use of pretreatment methods and membranes surface modification should be comprehensively studied to improve antifouling properties. The equilibrium model of fouling extends and operating conditions need to be optimized. Furthermore, the MBR cleaning reagents and versatile cleaning procedure need to be explored to ensure sustainable operation. Attempts to translate the technology from laboratory to industry-scale should aim to achieve a balance between sustainability and energy consumption.

4) The energy evaluation and techno-economic analysis are essential but lacking for large-scale MBR applications. In general, micropollutants generated from the pharmaceutical industries experience low removal efficiency with traditional MBRs and hence should be improved. The choices of membrane types, integration of separation units and operating conditions will significantly affect the removal efficiency of contaminants in hospital wastewater treatment. The two levels of integration have greatly

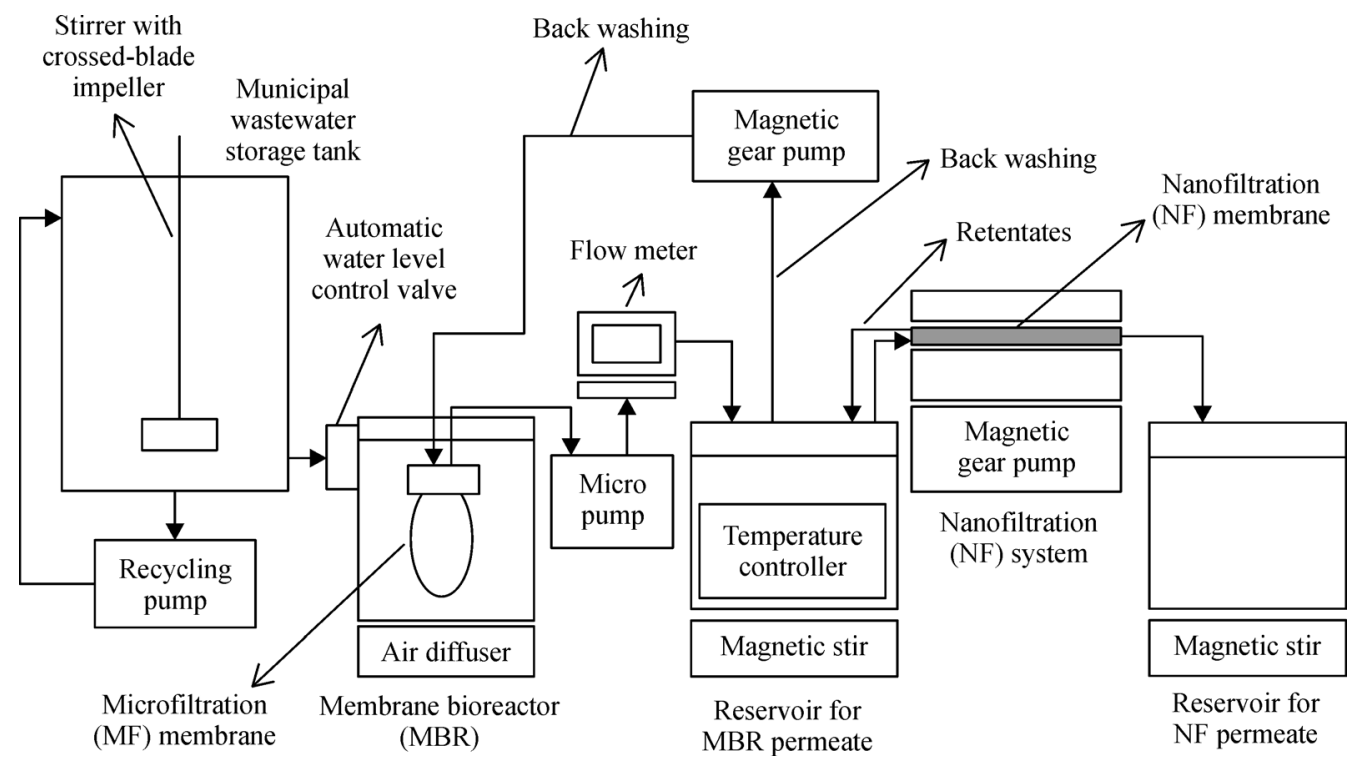

Fig. 11 The scheme of integrated MBR-NF systems. Reprinted with permission from ref. [250], copyright 2011, Elsevier. 
extended the applications of MBR systems, i.e., hybridizing novel membranes into the MBR units (namely hybrid MBRs), or MBR as a pretreatment step and integrating other membrane processes as a purification step (namely integrated MBR-membrane systems). The latter offers more flexibility and process stability, and lower operation cost, thus better scalability for industrial applications.

Through this review, it believes that the advancement in MBR concepts and systems exhibit great potential in assisting hospital wastewater treatment and hence contributing toward epidemic prevention.

Acknowledgements Yan Zhao would like to acknowledge the support provided by the China Scholarship Council (CSC) of the Ministry of Education, China (CSC No. 201708330281).

\section{References}

1. Wolfel R, Corman V M, Guggemos W, Seilmaier M, Zange S, Muller M A, Niemeyer D, Jones T C, Vollmar P, Rothe C, et al. Virological assessment of hospitalized patients with COVID-2019. Nature, 2020, 581(7809): 465-469

2. Wu F, Zhao S, Yu B, Chen Y M, Wang W, Song Z G, Hu Y, Tao Z W, Tian J H, Pei Y Y, et al. A new coronavirus associated with human respiratory disease in China. Nature, 2020, 579(7798): 265-269

3. Wu J T, Leung K, Bushman M, Kishore N, Niehus R, de Salazar P M, Cowling B J, Lipsitch M, Leung G M. Estimating clinical severity of COVID-19 from the transmission dynamics in Wuhan, China. Nature Medicine, 2020, 26(4): 506-510

4. Qu G, Li X, Hu L, Jiang G. An imperative need for research on the role of environmental factors in transmission of novel coronavirus (COVID-19). Environmental Science \& Technology, 2020, 54(7): 3730-3732

5. Liu Y, Gu P, Yang Y, Jia L, Zhang M, Zhang G. Removal of radioactive iodide from simulated liquid waste in an integrated precipitation reactor and membrane separator (PR-MS) system. Separation and Purification Technology, 2016, 171: 221-228

6. Feng X, Zong Z, Elsaidi S K, Jasinski J B, Krishna R, Thallapally P $\mathrm{K}$, Carreon M A. $\mathrm{Kr} / \mathrm{Xe}$ separation over a chabazite zeolite membrane. Journal of the American Chemical Society, 2016, 138(31): 9791-9794

7. Liu Y J, Lo S L, Liou Y H, Hu C Y. Removal of nonsteroidal antiinflammatory drugs (NSAIDs) by electrocoagulation-flotation with a cationic surfactant. Separation and Purification Technology, 2015, 152: 148-154

8. Xu Y, Li X, Zhu B, Liang H, Fang C, Gong Y, Guo Q, Sun X, Zhao D, Shen J, et al. Characteristics of pediatric SARS-CoV-2 infection and potential evidence for persistent fecal viral shedding. Nature Medicine, 2020, 26(4): 502-505

9. Luo Y, Feng L, Liu Y, Zhang L. Disinfection by-products formation and acute toxicity variation of hospital wastewater under different disinfection processes. Separation and Purification Technology, 2020, 238: 116405
10. Liu Q, Zhou Y, Chen L, Zheng X. Application of MBR for hospital wastewater treatment in China. Desalination, 2010, 250(2): 605608

11. Gautam A K, Kumar S, Sabumon P C. Preliminary study of physico-chemical treatment options for hospital wastewater. Journal of Environmental Management, 2007, 83(3): 298-306

12. Watson K, Shaw G, Leusch F D, Knight N L. Chlorine disinfection by-products in wastewater effluent: bioassay-based assessment of toxicological impact. Water Research, 2012, 46(18): 6069-6083

13. Chen W, Su Y, Peng J, Zhao X, Jiang Z, Dong Y, Zhang Y, Liang Y, Liu J. Efficient wastewater treatment by membranes through constructing tunable antifouling membrane surfaces. Environmental Science \& Technology, 2011, 45(15): 6545-6552

14. Zhao Y, Liu Y, Wang C, Ortega E, Wang X, Xie Y F, Shen J, Gao C, Van der Bruggen B. Electric field-based ionic control of selective separation layers. Journal of Materials Chemistry. A, Materials for Energy and Sustainability, 2020, 8(8): 4244-4251

15. Tang $\mathrm{Y}$ P, Luo L, Thong $Z$, Chung $T$ S. Recent advances in membrane materials and technologies for boron removal. Journal of Membrane Science, 2017, 541: 434-446

16. Nunes S P, Culfaz-Emecen P Z, Ramon G Z, Visser T, Koops G H, Jin W, Ulbricht $M$. Thinking the future of membranes: perspectives for advanced and new membrane materials and manufacturing processes. Journal of Membrane Science, 2020, 598: 117761

17. Li X, Mo Y, Qing W, Shao S, Tang C Y, Li J. Membrane-based technologies for lithium recovery from water lithium resources: a review. Journal of Membrane Science, 2019, 591: 117317

18. Li P, Wang Z, Qiao Z, Liu Y, Cao X, Li W, Wang J, Wang S. Recent developments in membranes for efficient hydrogen purification. Journal of Membrane Science, 2015, 495: 130-168

19. Uliana A A, Bui N T, Kamcev J, Taylor M K, Urban J J, Long J R. Ion-capture electrodialysis using multifunctional adsorptive membranes. Science, 2021, 372(6539): 296-299

20. Chaudhry R M, Nelson K L, Drewes J E. Mechanisms of pathogenic virus removal in a full-scale membrane bioreactor. Environmental Science \& Technology, 2015, 49(5): 2815-2822

21. Bodzek M, Konieczny K, Rajca M. Membranes in water and wastewater disinfection-review. Archives of Environmental Protection, 2019, 45: 3-18

22. Vieira W T, de Farias M B, Spaolonzi M P, Carlos da Silva M G, Adeodato Vieira M G. Removal of endocrine disruptors in waters by adsorption, membrane filtration and biodegradation. A review. Environmental Chemistry Letters, 2020, 18(4): 1113-1143

23. Bradshaw J L, Ashoori N, Osorio M, Luthy R G. Modelingcost, energy, and total organic carbon trade-offs for stormwater spreading basin systems receiving recycled water produced using membrane-based, ozone-based, and hybrid advanced treatment trains. Environmental Science \& Technology, 2019, 53(6): 31283139

24. Carolin C F, Kumar P S, Joshiba G J, Kumar V V. Analysis and removal of pharmaceutical residues from wastewater using membrane bioreactors: a review. Environmental Chemistry Letters, 2021, 19(1): 329-343

25. Yin X, Li J, Li X, Hua Z, Wang X, Ren Y. Self-generated electric field to suppress sludge production and fouling development in a membrane bioreactor for wastewater treatment. Chemosphere, 
2020, 261: 128046

26. Hu Y, Cheng H, Ji J, Li Y Y. A review of anaerobic membrane bioreactors for municipal wastewater treatment with a focus on multicomponent biogas and membrane fouling control. Environmental Science. Water Research \& Technology, 2020, 6(10): 2641-2663

27. Tiwari B, Sellamuthu B, Piche-Choquette S, Drogui P, Tyagi R D, Vaudreuil M A, Sauve S, Buelna G, Dube R. Acclimatization of microbial community of submerged membrane bioreactor treating hospital wastewater. Bioresource Technology, 2021, 319: 124223

28. Taoufik N, Boumya W, Janani F Z, Elhalil A, Mahjoubi F Z, Barka N. Removal of emerging pharmaceutical pollutants: a systematic mapping study review. Journal of Environmental Chemical Engineering, 2020, 8(5): 104251

29. Qin L, Gao M, Zhang M, Feng L, Liu Q, Zhang G. Application of encapsulated algae into MBR for high-ammonia nitrogen wastewater treatment and biofouling control. Water Research, 2020, 187: 116430

30. Xu Z, Song X, Xie M, Wang Y, Huda N, Li G, Luo W. Effects of surfactant addition to draw solution on the performance of osmotic membrane bioreactor. Journal of Membrane Science, 2021, 618: 118634

31. Wang S, Chew J W, Liu Y. Development of an integrated aerobic granular sludge MBR and reverse osmosis process for municipal wastewater reclamation. Science of the Total Environment, 2020, 748: 141309

32. Song W, Xu D, Bi X, Ng H Y, Shi X. Intertidal wetland sediment as a novel inoculation source for developing aerobic granular sludge in membrane bioreactor treating high-salinity antibiotic manufacturing wastewater. Bioresource Technology, 2020, 314: 123715

33. Pervez M N, Balakrishnan M, Hasan S W, Choo K H, Zhao Y, Cai $\mathrm{Y}$, Zarra T, Belgiorno V, Naddeo V. A critical review on nanomaterials membrane bioreactor (NMs-MBR) for wastewater treatment. npj Clean Water, 2020, 3: 43

34. Verlicchi P, Galletti A, Petrovic M, Barceló D. Hospital effluents as a source of emerging pollutants: an overview of micropollutants and sustainable treatment options. Journal of Hydrology, 2010, 389(3-4): 416-428

35. Wiedenheft B, Sternberg S H, Doudna J A. RNA-guided genetic silencing systems in bacteria and archaea. Nature, 2012, 482(7385): 331-338

36. Paez-Espino D, Eloe-Fadrosh E A, Pavlopoulos G A, Thomas A D, Huntemann M, Mikhailova N, Rubin E, Ivanova N N, Kyrpides N C. Uncovering Earth's virome. Nature, 2016, 536(7617): 425-430

37. Schulz F, Roux S, Paez-Espino D, Jungbluth S, Walsh D A, Denef V J, McMahon K D, Konstantinidis K T, Eloe-Fadrosh E A, Kyrpides N C, et al. Giant virus diversity and host interactions through global metagenomics. Nature, 2020, 578(7795): 432-436

38. Casanova L, Rutala W A, Weber D J, Sobsey M D. Survival of surrogate coronaviruses in water. Water Research, 2009, 43(7): 1893-1898

39. Carraro E, Bonetta S, Bertino C, Lorenzi E, Bonetta S, Gilli G. Hospital effluents management: chemical, physical, microbiological risks and legislation in different countries. Journal of Environmental Management, 2016, 168: 185-199
40. Hai F, Riley T, Shawkat S, Magram S, Yamamoto K. Removal of pathogens by membrane bioreactors: a review of the mechanisms, influencing factors and reduction in chemical disinfectant dosing. Water, 2014, 6(12): 3603-3630

41. Yates M V. Adenovirus. In: Microbiology of Waterborne Diseases. 2nd ed. Amsterdam: Elsevier, 2014, 471-477

42. Elmahdy E M, Ahmed N I, Shaheen M N F, Mohamed E C B, Loutfy S A. Molecular detection of human adenovirus in urban wastewater in Egypt and among children suffering from acute gastroenteritis. Journal of Water and Health, 2019, 17(2): 287-294

43. Yates M V. Astroviruses. In: Microbiology of Waterborne Diseases. 2nd ed. Amsterdam: Elsevier, 2014, 479-491

44. He X Q, Cheng L, Zhang D Y, Xie X M, Wang D H, Wang Z. Oneyear monthly survey of rotavirus, astrovirus and norovirus in three sewage treatment plants in Beijing, China and associated health risk assessment. Water Science and Technology, 2011, 63(1): 191198

45. Wathore R, Gupta A, Bherwani H, Labhasetwar N. Understanding air and water borne transmission and survival of coronavirus: insights and way forward for SARS-CoV-2. Science of the Total Environment, 2020, 749: 141486

46. Kataki S, Chatterjee S, Vairale M G, Sharma S, Dwivedi S K. Concerns and strategies for wastewater treatment during COVID19 pandemic to stop plausible transmission. Resources, Conservation and Recycling, 2021, 164: 105156

47. Yates M V. Enterovirus. In: Microbiology of Waterborne Diseases. 2nd ed. Amsterdam: Elsevier, 2014, 493-504

48. La Rosa G, Pourshaban M, Iaconelli M, Muscillo M. Quantitative real-time PCR of enteric viruses in influent and effluent samples from wastewater treatment plants in Italy. Environmental Issues of Health Concern, 2010, 46: 266-273

49. Yates M V. Hepatitis A Virus (HAV). In: Microbiology of Waterborne Diseases. 2nd ed. Amsterdam: Elsevier, 2014, 505513

50. Yates M V. Norovirus. In: Microbiology of Waterborne Diseases. 2nd ed. Amsterdam: Elsevier, 2014, 515-522

51. Okoh A I, Sibanda T, Gusha S S. Inadequately treated wastewater as a source of human enteric viruses in the environment. International Journal of Environmental Research and Public Health, 2010, 7(6): 2620-2637

52. Yates M V. Emerging Viruses. In: Microbiology of Waterborne Diseases. 2nd ed. Amsterdam: Elsevier, 2014, 529-533

53. Ibrahim C, Hammami S, Chérif N, Mejri S, Pothier P, Hassen A. Detection of sapoviruses in two biological lines of Tunisian hospital wastewater treatment. International Journal of Environmental Research and Public Health, 2019, 29(4): 400-413

54. Chalmers R M. Cryptosporidium. In: Microbiology of Waterborne Diseases. 2nd ed. Amsterdam: Elsevier, 2014, 287-326

55. Jiang W, Roellig D M, Li N, Wang L, Guo Y, Feng Y, Xiao L. Contribution of hospitals to the occurrence of enteric protists in urban wastewater. Parasitology Research, 2020, 119(9): 30333040

56. Chalmers R M. Entamoeba histolytica. In: Microbiology of Waterborne Diseases. 2nd ed. Amsterdam: Elsevier, 2014, 355373

57. Berglund B, Dienus O, Sokolova E, Berglind E, Matussek A, 
Pettersson T, Lindgren P E. Occurrence and removal efficiency of parasitic protozoa in Swedish wastewater treatment plants. Science of the Total Environment, 2017, 598: 821-827

58. Robertson L J. Giardia duodenalis. In: Microbiology of Waterborne Diseases. 2nd ed. Amsterdam: Elsevier, 2014, 375-405

59. Percival S L, Williams D W. Campylobacter. In: Microbiology of Waterborne Diseases. 2nd ed. Amsterdam: Elsevier, 2014, 65-78

60. Rinsoz T, Hilfiker S, Oppliger A. Quantification of thermotolerant campylobacter in Swiss water treatment plants, by real-time quantitative polymerase chain reaction. Water Environment Research, 2009, 81(9): 929-933

61. Percival S L, Williams D W. Escherichia coli. In: Microbiology of Waterborne Diseases. 2nd ed. Amsterdam: Elsevier. 2014, 89-117

62. Kristanto G A, Koven W. Preliminary study of antibiotic resistant Escherichia coli in hospital wastewater treatment plants in Indonesia. International Journal of Technology, 2019, 10(4): 765

63. Percival S L, Williams D W. Legionella. In: Microbiology of Waterborne Diseases. 2nd ed. Amsterdam: Elsevier, 2014, 155175

64. Huang S W, Hsu B M, Ma P H, Chien K T. Legionella prevalence in wastewater treatment plants of Taiwan. Water Science and Technology, 2009, 60(5): 1303-1310

65. Nuñez L, Moretton J. Disinfectant-resistant bacteria in Buenos Aires city hospital wastewater. Brazilian Journal of Microbiology, 2007, 38(4): 644-648

66. Percival S L, Williams D W. Salmonella. In: Microbiology of Waterborne Diseases. 2nd ed. Amsterdam: Elsevier, 2014, 209222

67. Fekadu S, Merid Y, Beyene H, Teshome W, Gebre-Selassie S. Assessment of antibiotic- and disinfectant-resistant bacteria in hospital wastewater, south Ethiopia: a cross-sectional study. Journal of Infection in Developing Countries, 2015, 9(02): 149156

68. Tsai C T, Lai J S, Lin S T. Quantification of pathogenic microorganisms in the sludge from treated hospital wastewater. Journal of Applied Microbiology, 1998, 85(1): 171-176

69. Percival S L, Williams D W. Shigella. In: Microbiology of Waterborne Diseases. 2nd ed. Amsterdam: Elsevier, 2014, 223236

70. Percival S L, Williams D W. Vibrio. In: Microbiology of Waterborne Diseases. 2nd ed. Amsterdam: Elsevier, 2014, 237248

71. Nongogo V, Okoh A. Occurrence of vibrio pathotypes in the final effluents of five waste water treatment plants in Amathole and Chris Hani District Municipalities in South Africa. International Journal of Environmental Research and Public Health, 2014, 11(8): 7755-7766

72. Leekha S, Terrell C L, Edson R S. General principles of antimicrobial therapy. Mayo Clinic Proceedings, 2011, 86(2): 156-167

73. Singer A C, Jarhult J D, Grabic R, Khan G A, Lindberg R H, Fedorova G, Fick J, Bowes M J, Olsen B, Soderstrom H. Intra- and inter-pandemic variations of antiviral, antibiotics and decongestants in wastewater treatment plants and receiving rivers. PLoS One, 2014, 9(9): 108621

74. Senta I, Kostanjevecki P, Krizman-Matasic I, Terzic S, Ahel M.
Occurrence and behavior of macrolide antibiotics in municipal wastewater treatment: possible importance of metabolites, synthesis byproducts, and transformation products. Environmental Science \& Technology, 2019, 53(13): 7463-7472

75. Zhang H C, Zhang M Q, Yuan L, Zhang X, Sheng G P. Synergistic effect of permanganate and in situ synthesized hydrated manganese oxide for removing antibiotic resistance genes from wastewater treatment plant effluent. Environmental Science \& Technology, 2019, 53(22): 13374-13381

76. Nannou C, Ofrydopoulou A, Evgenidou E, David H, Heath E, Lambropoulou D. Antiviral drugs in aquatic environment and wastewater treatment plants: a review on occurrence, fate, removal and ecotoxicity. Science of the Total Environment, 2020, 699: 134322

77. Frederic O, Yves P. Pharmaceuticals in hospital wastewater: their ecotoxicity and contribution to the environmental hazard of the effluent. Chemosphere, 2014, 115: 31-39

78. Prasse C, Schlusener M P, Ralf S, Ternes T A. Antiviral drugs in wastewater and surface waters: a new pharmaceutical class of environmental relevance? Environmental Science \& Technology, 2010, 44(5): 1728-1735

79. Accinelli C, Sacca M L, Batisson I, Fick J, Mencarelli M, Grabic R. Removal of oseltamivir (Tamiflu) and other selected pharmaceuticals from wastewater using a granular bioplastic formulation entrapping propagules of Phanerochaete chrysosporium. Chemosphere, 2010, 81(3): 436-443

80. Slater F R, Singer A C, Turner S, Barr J J, Bond P L. Pandemic pharmaceutical dosing effects on wastewater treatment: no adaptation of activated sludge bacteria to degrade the antiviral drug oseltamivir (Tamiflu(R)) and loss of nutrient removal performance. FEMS Microbiology Letters, 2011, 315(1): 17-22

81. Fugere V, Hebert M P, da Costa N B, Xu C C Y, Barrett R D H, Beisner B E, Bell G, Fussmann G F, Shapiro B J, Yargeau V, Gonzalez A. Community rescue in experimental phytoplankton communities facing severe herbicide pollution. Nature Ecology \& Evolution, 2020, 4(4): 578-588

82. Berendonk T U, Manaia C M, Merlin C, Fatta-Kassinos D, Cytryn E, Walsh F, Burgmann H, Sorum H, Norstrom M, Pons M N, et al. Tackling antibiotic resistance: the environmental framework. Nature Reviews. Microbiology, 2015, 13(5): 310-317

83. Rodriguez-Mozaz S, Chamorro S, Marti E, Huerta B, Gros M, Sànchez-Melsió A, Borrego $\mathrm{C}$ M, Barceló $\mathrm{D}$, Balcázar J L. Occurrence of antibiotics and antibiotic resistance genes in hospital and urban wastewaters and their impact on the receiving river. Water Research, 2015, 69: 234-242

84. Wang Y, Wang X, Li M, Dong J, Sun C, Chen G. Removal of pharmaceutical and personal care products (PPCPs) from municipal waste water with integrated membrane systems, MBR-RO/NF. International Journal of Environmental Research and Public Health, 2018, 15(2): 269

85. Lien L, Hoa N, Chuc N, Thoa N, Phuc H, Diwan V, Dat N, Tamhankar A, Lundborg C. Antibiotics in wastewater of a rural and an urban hospital before and after wastewater treatment, and the relationship with antibiotic use-A one year study from Vietnam. International Journal of Environmental Research and Public Health, 2016, 13(6): 588 
86. Kümmerer K. Drugs in the environment: emission of drugs, diagnostic aids and disinfectants into wastewater by hospitals in relation to other sources: a review. Chemosphere, 2001, 45(6-7): 957-969

87. Kovalova L, Siegrist H, Singer H, Wittmer A, Mcardell C S. Hospital wastewater treatment by membrane bioreactor: performance and efficiency for organic micropollutant elimination. Environmental Science \& Technology, 2012, 46(3): 1536-1545

88. Moradali M F, Rehm B H A. Bacterial biopolymers: from pathogenesis to advanced materials. Nature Reviews. Microbiology, 2020, 18(4): 195-210

89. Reurink D M, Te Brinke E, Achterhuis I, Roesink H D W, de Vos W M. Nafion-based low-hydration polyelectrolyte multilayer membranes for enhanced water purification. ACS Applied Polymer Materials, 2019, 1(9): 2543-2551

90. Amaral-Zettler L A, Zettler E R, Mincer T J. Ecology of the plastisphere. Nature Reviews. Microbiology, 2020, 18(3): 139-151

91. Barry M C, Hristovski K, Westerhoff P. Membrane fouling by vesicles and prevention through ozonation. Environmental Science \& Technology, 2014, 48(13): 7349-7356

92. Wang L, Li Y, Ben W, Hu J, Cui Z, Qu K, Qiang Z. In-situ sludge ozone-reduction process for effective removal of fluoroquinolone antibiotics in wastewater treatment plants. Separation and Purification Technology, 2019, 213: 419-425

93. Loeb S K, Alvarez P J J, Brame J A, Cates E L, Choi W, Crittenden J, Dionysiou D D, Li Q, Li-Puma G, Quan X, et al. The Technology horizon for photocatalytic water treatment: sunrise or sunset? Environmental Science \& Technology, 2019, 53(6): 2937-2947

94. Lienert J, Koller M, Konrad J, McArdell C S, Schuwirth N. Multiple-criteria decision analysis reveals high stakeholder preference to remove pharmaceuticals from hospital wastewater. Environmental Science \& Technology, 2011, 45(9): 3848-3857

95. Kosma C I, Lambropoulou D A, Albanis T A. Occurrence and removal of PPCPs in municipal and hospital wastewaters in Greece. Journal of Hazardous Materials, 2010, 179(1-3): 804-817

96. Gurung K, Ncibi M C, Thangaraj S K, Jänis J, Seyedsalehi M, Sillanpää M. Removal of pharmaceutically active compounds (PhACs) from real membrane bioreactor (MBR) effluents by photocatalytic degradation using composite $\mathrm{Ag}_{2} \mathrm{O} / \mathrm{P}-25$ photocatalyst. Separation and Purification Technology, 2019, 215: 317328

97. Dong X, Ge Q. Metal ion-bridged forward osmosis membranes for efficient pharmaceutical wastewater reclamation. ACS Applied Materials \& Interfaces, 2019, 11(40): 37163-37171

98. Kramer M, Scifoni E, Schuy C, Rovituso M, Tinganelli W, Maier A, Kaderka R, Kraft-Weyrather W, Brons S, Tessonnier T, et al. Helium ions for radiotherapy? Physical and biological verifications of a novel treatment modality. Medical Physics, 2016, 43(4): 1995-2004

99. Soyekwo F, Liu C, Zhao L, Wen H, Huang W, Cai C, Kanagaraj P, $\mathrm{Hu}$ Y. Nanofiltration membranes with metal cation-immobilized aminophosphonate networks for efficient heavy metal ion removal and organic dye degradation. ACS Applied Materials \& Interfaces, 2019, 11(33): 30317-30331

100. Sepehr M N, Nasseri S, Zarrabi M, Samarghandi M R, Amrane A. Removal of $\mathrm{Cr}(\mathrm{III})$ from tanning effluent by Aspergillus niger in airlift bioreactor. Separation and Purification Technology, 2012, 96: 256-262

101. Saitoh T, Shibata K, Fujimori K, Ohtani Y. Rapid removal of tetracycline antibiotics from water by coagulation-flotation of sodium dodecyl sulfate and poly(allylamine hydrochloride) in the presence of $\mathrm{Al}(\mathrm{III})$ ions. Separation and Purification Technology, 2017, 187: 76-83

102. Zhao Y, Zhou C, Wang J, Liu H, Xu Y, Seo J W, Shen J, Gao C, Van der Bruggen B. Formation of morphologically confined nanospaces via self-assembly of graphene and nanospheres for selective separation of lithium. Journal of Materials Chemistry. A, Materials for Energy and Sustainability, 2018, 6(39): 18859-18864

103. Zhao Y, Qiu Y, Mai Z, Ortega E, Shen J, Gao C, van der Bruggen B. Symmetrically recombined nanofibers in a high-selectivity membrane for cation separation in high temperature and organic solvent. Journal of Materials Chemistry. A, Materials for Energy and Sustainability, 2019, 7(34): 20006-20012

104. Zhao Y, Tang K, Liu H, van der Bruggen B, Sotto Díaz A, Shen J, Gao C. An anion exchange membrane modified by alternate electro-deposition layers with enhanced monovalent selectivity. Journal of Membrane Science, 2016, 520: 262-271

105. Helmi A, Gallucci F. Latest developments in membrane (bio) reactors. Processes (Basel, Switzerland), 2020, 8(10): 1239

106. Gunder B, Krauth K. Replacement of secondary clarification by membrane separation-results with plate and hollow fibre modules. Water Science and Technology, 1998, 40(4-5): 311-320

107. Lv W, Xiang Z, Min Y, Yu Z, Ying L, Liu J. Virus removal performance and mechanism of a submerged membrane bioreactor. Process Biochemistry, 2006, 41(2): 299-304

108. Stuckey D C. Recent developments in anaerobic membrane reactors. Bioresource Technology, 2012, 122: 137-148

109. Ahmad A L, Abdulkarim A A, Ooi B S, Ismail S. Recent development in additives modifications of polyethersulfone membrane for flux enhancement. Chemical Engineering Journal, 2013, 223: 246-267

110. Meng F, Chae S R, Drews A, Kraume M, Shin H S, Yang F. Recent advances in membrane bioreactors (MBRs): membrane fouling and membrane material. Water Research, 2009, 43(6): 1489-1512

111. Samaei S M, Gato-Trinidad S, Ali A. The application of pressuredriven ceramic membrane technology for the treatment of industrial wastewaters: a review. Separation and Purification Technology, 2018, 200: 198-220

112. Mbaab C, Zzab C. Ceramic membrane technology for water and wastewater treatment: a critical review of performance, full-scale applications, membrane fouling and prospects. Chemical Engineering Journal, 2021, 418: 129418

113. Zhang S, Qu Y, Liu Y, Yang F, Yamada Y. Experimental study of domestic sewage treatment with a metal membrane bioreactor. Desalination, 2005, 177(1-3): 83-93

114. Xie Y H, Zhu T, Xu C H, Nozaki T, Furukawa K. Treatment of domestic sewage by a metal membrane bioreactor. Water Science and Technology, 2012, 65(6): 1102-1108

115. Dumée L, Li H, Bao L, Ailloux F M, Kong L. The fabrication and surface functionalization of porous metal frameworks - a review. Journal of Materials Chemistry. A, Materials for Energy and Sustainability, 2013, 1(48): 15185 
116. Dlamini D S, Li J, Mamba B B. Critical review of montmorillonite/ polymer mixed-matrix filtration membranes: possibilities and challenges. Applied Clay Science, 2019, 168: 21-30

117. Bilad M R, Marbelia L, Laine C, Vankelecom I. A PVC-silica mixed-matrix membrane (MMM) as novel type of membrane bioreactor (MBR) membrane. Journal of Membrane Science, 2015, 493: 19-27

118. Mathioudakis V L, Soares A, Briers H, Martin-Garcia I, Jefferson B. Treatment and energy efficiency of a granular sludge anaerobic membrane reactor handling domestic sewage. Procedia Engineering, 2012, 44: 1977-1979

119. Lin H J, Xie K, Mahendran B, Ba Gley D M, Leung K T, Liss S N, Liao B Q. Sludge properties and their effects on membrane fouling in submerged anaerobic membrane bioreactors (SAnMBRs). Water Research, 2009, 43(15): 3827-3837

120. Lin H, Chen J, Wang F, Ding L, Hong H. Feasibility evaluation of submerged anaerobic membrane bioreactor for municipal secondary wastewater treatment. Desalination, 2011, 280(1-3): 120-126

121. Chen R, Nie Y, Kato H, Wu J, Utashiro T, Lu J, Yue S, Jiang H, Zhang L, Li Y Y. Methanogenic degradation of toilet-paper cellulose upon sewage treatment in an anaerobic membrane bioreactor at room temperature. Bioresource Technology, 2017, 228: 69-76

122. Nie Y, Kato H, Sugo T, Hojo T, Tian X, Li Y Y. Effect of anionic surfactant inhibition on sewage treatment by a submerged anaerobic membrane bioreactor: efficiency, sludge activity and methane recovery. Chemical Engineering Journal, 2017, 315: 8391

123. Hui C, Yutaka H, Toshimasa H, Li Y Y. Upgrading methane fermentation of food waste by using a hollow fiber type anaerobic membrane bioreactor. Bioresource Technology, 2018, 267: 386394

124. Trzcinski A P, Stuckey D C. Continuous treatment of the organic fraction of municipal solid waste in an anaerobic two-stage membrane process with liquid recycle. Water Research, 2009, 43(9): 2449-2462

125. Akram A, Stuckey D C. Flux and performance improvement in a submerged anaerobic membrane bioreactor (SAMBR) using powdered activated carbon (PAC). Process Biochemistry, 2008, 43(1): 93-102

126. Nie Y, Chen R, Tian X, Li Y Y. Impact of water characteristics on the bioenergy recovery from sewage treatment by anaerobic membrane bioreactor via a comprehensive study on the response of microbial community and methanogenic activity. Energy, 2017, 139(15): 459-467

127. Jang D, Hwang Y, Shin H, Lee W. Effects of salinity on the characteristics of biomass and membrane fouling in membrane bioreactors. Bioresource Technology, 2013, 141: 50-56

128. Tan S, Cui C, Chen X, Li W. Effect of bioflocculation on foulingrelated biofoulants in a membrane bioreactor during saline wastewater treatments. Bioresource Technology, 2017, 224: 285291

129. Biesheuvel P M, Verweij H. Design of ceramic membrane supports: permeability, tensile strength and stress. Journal of Membrane Science, 1999, 156(1): 141-152

130. Sownya S A, Madhu G M, Raizada A, Madhusoodana C D.
Studies on effective treatment of waste water using submerged ceramic membrane bioreactor. Materials Today: Proceedings, 2020, 24: 1251-1262

131. Trouve E, Urbain V, Manem J. Treatment of municipal wastewater by a membrane bioreactor: results of a semi-industrial pilot-scale study. Water Science and Technology, 1994, 30(4): 151-157

132. Zhang S, Yang F, Liu Y, Zhang X, Yamada Y, Furukawa K. Performance of a metallic membrane bioreactor treating simulated distillery wastewater at temperatures of 30 to $45^{\circ} \mathrm{C}$. Desalination, 2006, 194(1-3): 146-155

133. Reif R, Besancon A, Le Corre K, Jefferson B, Lema J M, Omil F. Comparison of PPCPs removal on a parallel-operated MBR and AS system and evaluation of effluent post-treatment on vertical flow reed beds. Water ence \& Technology, 2011, 63: 2411-2417

134. Wang J, Wang S. Removal of pharmaceuticals and personal care products (PPCPs) from wastewater: a review. Journal of Environmental Management, 2016, 182: 620-640

135. $\mathrm{Ng} \mathrm{A}, \mathrm{Kim} \mathrm{A} \mathrm{S}$. A mini-review of modeling studies on membrane bioreactor (MBR) treatment for municipal wastewaters. Desalination, 2007, 212(1-3): 261-281

136. Yurtsever A, Sahinkaya E, Akta Z, Uar D, Wang Z. Performances of anaerobic and aerobic membrane bioreactors for the treatment of synthetic textile wastewater. Bioresource Technology, 2015, 192 : 564-573

137. Smith A L, Stadler L B, Cao L, Love N G, Raskin L, Skerlos S J. Navigating wastewater energy recovery strategies: a life cycle comparison of anaerobic membrane bioreactor and conventional treatment systems with anaerobic digestion. Environmental Science \& Technology, 2014, 48(10): 5972-5981

138. Liu W, Song X, Huda N, Xie M, Li G, Luo W. Comparison between aerobic and anaerobic membrane bioreactors for trace organic contaminant removal in wastewater treatment. Environmental Technology \& Innovation, 2020, 17: 100564

139. Monteoliva-Garcia A, Martin-Pascual J, Munio M M, Poyatos J M. Effects of carrier addition on water quality and pharmaceutical removal capacity of a membrane bioreactor - advanced oxidation process combined treatment. Science of the Total Environment, 2020, 708: 135104

140. Xiao K, Liang S, Wang X, Chen C, Huang X. Current state and challenges of full-scale membrane bioreactor applications: a critical review. Bioresource Technology, 2019, 271: 473-481

141. Blandin G, Gautier C, Sauchelli Toran M, Monclús H, RodriguezRoda I, Comas J. Retrofitting membrane bioreactor (MBR) into osmotic membrane bioreactor (OMBR): a pilot scale study. Chemical Engineering Journal, 2018, 339: 268-277

142. Li X, Liu Y, Wang J, Gascon J, Li J, van der Bruggen B. Metalorganic frameworks based membranes for liquid separation. Chemical Society Reviews, 2017, 46(23): 7124-7144

143. Chen $\mathrm{X}$, Selloni A. Introduction: titanium dioxide $\left(\mathrm{TiO}_{2}\right)$ nanomaterials. Chemical Reviews, 2014, 114(19): 9281-9282

144. Tiwari J N, Tiwari R N, Kim K S. Zero-dimensional, onedimensional, two-dimensional and three-dimensional nanostructured materials for advanced electrochemical energy devices. Progress in Materials Science, 2012, 57(4): 724-803

145. Sutisna B, Musteata V, Pulido B, Puspasari T, Smilgies D M, Hadjichristidis N, Nunes S P. High flux membranes, based on self- 
assembled and H-bond linked triblock copolymer nanospheres. Journal of Membrane Science, 2019, 585: 10-18

146. Yan W, Shi M, Wang Z, Zhou Y, Liu L, Zhao S, Ji Y, Wang J, Gao C. Amino-modified hollow mesoporous silica nanospheresincorporated reverse osmosis membrane with high performance. Journal of Membrane Science, 2019, 581: 168-177

147. Zou D, Chen X, Drioli E, Ke X, Qiu M, Fan Y. Facile co-sintering process to fabricate sustainable antifouling silver nanoparticles (AgNPs)-enhanced tight ceramic ultrafiltration membranes for protein separation. Journal of Membrane Science, 2020, 593: 117402

148. Hinds B J, Chopra N, Rantell T, Andrews R, Gavalas V, Bachas L G. Aligned multiwalled carbon nanotube membranes. Science, 2004, 303(5654): 62-65

149. Sholl D S, Johnson J K. Making high-flux membranes with carbon nanotubes. Science, 2006, 312(5776): 1003-1004

150. Zhao X, Cheng L, Wang R, Jia N, Liu L, Gao C. Bioinspired synthesis of polyzwitterion/titania functionalized carbon nanotube membrane with superwetting property for efficient oil-in-water emulsion separation. Journal of Membrane Science, 2019, 589: 117257

151. Li J, Li X, van der Bruggen B. An MXene-based membrane for molecular separation. Environmental Science. Nano, 2020, 7(5): 1289-1304

152. Zhao Y, Wu M, Guo Y, Mamrol N, Yang X, Gao C, van der Bruggen B. Metal-organic framework based membranes for selective separation of target ions. Journal of Membrane Science, 2021, 634: 119407

153. Yang H, Yang L, Wang H, Xu Z, Zhao Y, Luo Y, Nasir N, Song Y, Wu H, Pan F, Jiang Z. Covalent organic framework membranes through a mixed-dimensional assembly for molecular separations. Nature Communications, 2019, 10(1): 2101

154. Gao Z F, Feng Y, Ma D, Chung T S. Vapor-phase crosslinked mixed matrix membranes with $\mathrm{UiO}-66-\mathrm{NH}_{2}$ for organic solvent nanofiltration. Journal of Membrane Science, 2019, 574: 124-135

155. Gao Z F, Naderi A, Wei W, Chung T S. Selection of crosslinkers and control of microstructure of vapor-phase crosslinked composite membranes for organic solvent nanofiltration. Journal of Membrane Science, 2020, 616: 118582

156. Lee T H, Oh J Y, Hong S P, Lee J M, Roh S M, Kim S H, Park H B. ZIF-8 particle size effects on reverse osmosis performance of polyamide thin-film nanocomposite membranes: importance of particle deposition. Journal of Membrane Science, 2019, 570-571: 23-33

157. Zhao D L, Zhao Q, Chung T S. Fabrication of defect-free thin-film nanocomposite (TFN) membranes for reverse osmosis desalination. Desalination, 2021, 516: 115230

158. Zhang Z, Li P, Kong X Y, Xie G, Qian Y, Wang Z, Tian Y, Wen L, Jiang L. Bioinspired heterogeneous ion pump membranes: unidirectional selective pumping and controllable gating properties stemming from asymmetric ionic group distribution. Journal of the American Chemical Society, 2018, 140(3): 1083-1090

159. Yan S, Luan S, Shi H, Xu X, Zhang J, Yuan S, Yang Y, Yin J. Hierarchical polymer brushes with dominant antibacterial mechanisms switching from bactericidal to bacteria repellent. Biomacromolecules, 2016, 17(5): 1696-1704
160. Shahid M K, Choi Y G. The comparative study for scale inhibition on surface of RO membranes in wastewater reclamation: $\mathrm{CO}_{2}$ purging versus three different antiscalants. Journal of Membrane Science, 2018, 546: 61-69

161. Wang Z, Wu Z, Yin X, Tian L. Membrane fouling in a submerged membrane bioreactor (MBR) under sub-critical flux operation: membrane foulant and gel layer characterization. Journal of Membrane Science, 2008, 325(1): 238-244

162. Mikhaylin S, Bazinet L. Fouling on ion-exchange membranes: classification, characterization and strategies of prevention and control. Advances in Colloid and Interface Science, 2016, 229: 3456

163. Firouzjaei M D, Seyedpour S F, Aktij S A, Giagnorio M, Bazrafshan N, Mollahosseini A, Samadi F, Ahmadalipour S, Firouzjaei F D, Esfahani M R, et al. Recent advances in functionalized polymer membranes for biofouling control and mitigation in forward osmosis. Journal of Membrane Science, 2020, 596: 117604

164. Malaeb L, Le-Clech P, Vrouwenvelder J S, Ayoub G M, Saikaly P E. Do biological-based strategies hold promise to biofouling control in MBRs? Water Research, 2013, 47(15): 5447-5463

165. Bogler A, Lin S, Bar-Zeev E. Biofouling of membrane distillation, forward osmosis and pressure retarded osmosis: principles, impacts and future directions. Journal of Membrane Science, 2017, 542: 378-398

166. Sánchez O. Microbial diversity in biofilms from reverse osmosis membranes: a short review. Journal of Membrane Science, 2018, 545: 240-249

167. Bar-Zeev E, Passow U, Castrillon S R, Elimelech M. Transparent exopolymer particles: from aquatic environments and engineered systems to membrane biofouling. Environmental Science \& Technology, 2015, 49(2): 691-707

168. Oh H S, Lee $\mathrm{C} \mathrm{H}$. Origin and evolution of quorum quenching technology for biofouling control in MBRs for wastewater treatment. Journal of Membrane Science, 2018, 554: 331-345

169. Ridgway H F, Orbell J, Gray S. Molecular simulations of polyamide membrane materials used in desalination and water reuse applications: recent developments and future prospects. Journal of Membrane Science, 2017, 524: 436-448

170. Kochkodan V, Johnson D J, Hilal N. Polymeric membranes: surface modification for minimizing (bio)colloidal fouling. Advances in Colloid and Interface Science, 2014, 206: 116-140

171. Dickhout J M, Moreno J, Biesheuvel P M, Boels L, Lammertink R G H, de Vos W M. Produced water treatment by membranes: a review from a colloidal perspective. Journal of Colloid and Interface Science, 2017, 487: 523-534

172. Al Mamun M A, Sadrzadeh M, Chatterjee R, Bhattacharjee S, De S. Colloidal fouling of nanofiltration membranes: a novel transient electrokinetic model and experimental study. Chemical Engineering Science, 2015, 138: 153-163

173. Dersoir B, Schofield A B, de Saint Vincent M R, Tabuteau H. Dynamics of pore fouling by colloidal particles at the particle level. Journal of Membrane Science, 2019, 573: 411-424

174. Lohaus J, Perez Y M, Wessling M. What are the microscopic events of colloidal membrane fouling? Journal of Membrane Science, 2018, 553: 90-98 
175. Haddad M, Bazinet L, Savadogo O, Paris J. Electrochemical acidification of Kraft black liquor: impacts of pulsed electric field application on bipolar membrane colloidal fouling and process intensification. Journal of Membrane Science, 2017, 524: 482-492

176. Lin Y L. Effects of organic, biological and colloidal fouling on the removal of pharmaceuticals and personal care products by nanofiltration and reverse osmosis membranes. Journal of Membrane Science, 2017, 542: 342-351

177. Mi B, Elimelech M. Organic fouling of forward osmosis membranes: fouling reversibility and cleaning without chemical reagents. Journal of Membrane Science, 2010, 348(1-2): 337-345

178. Wang X M, Waite T D. Role of gelling soluble and colloidal microbial products in membrane fouling. Environmental Science \& Technology, 2009, 43(24): 9341-9347

179. Wang Q, Wang Z, Wu Z, Ma J, Jiang Z. Insights into membrane fouling of submerged membrane bioreactors by characterizing different fouling layers formed on membrane surfaces. Chemical Engineering Journal, 2012, 179: 169-177

180. Zhao Y, Liu H, Tang K, Jin Y, Pan J, Van der Bruggen B, Shen J, Gao C. Mimicking the cell membrane: bio-inspired simultaneous functions with monovalent anion selectivity and antifouling properties of anion exchange membrane. Scientific Reports, 2016, 6(1): 37285

181. Amy G. Fundamental understanding of organic matter fouling of membranes. Desalination, 2008, 231(1-3): 44-51

182. Tong $\mathrm{T}$, Wallace A F, Zhao S, Wang Z. Mineral scaling in membrane desalination: mechanisms, mitigation strategies, and feasibility of scaling-resistant membranes. Journal of Membrane Science, 2019, 579: 52-69

183. Zhao Y, Yao M, Shen P, Uytterhoeven C, Marmrol N, Shen J, Gao C, Van der Bruggen B. Composite anti-scaling membrane made of interpenetrating networks of nanofibers for selective separation of lithium. Journal of Membrane Science, 2021, 618: 118668

184. Tinggang L I, Liu J, Bai R, Wong F S. Membrane-aerated biofilm reactor for the treatment of acetonitrile wastewater. Environmental Science \& Technology, 2008, 42(6): 2099-2104

185. Tian H, Hu Y, Xu X, Hui M, Li B. Enhanced wastewater treatment with high $o$-aminophenol concentration by two-stage MABR and its biodegradation mechanism. Bioresource Technology, 2019, 289: 121649

186. Tian H, Xu X, Qu J, Li H, Hu Y, Huang L, He W, Li B. Biodegradation of phenolic compounds in high saline wastewater by biofilms adhering on aerated membranes. Journal of Hazardous Materials, 2020, 392: 122463

187. Livingston A G. Extractive membrane bioreactors: a new process technology for detoxifying chemical industry wastewaters. Journal of Chemical Technology and Biotechnology (Oxford, Oxfordshire), 1994, 60(2): 117-124

188. Yeo B J, Goh S, Livingston A G, Fane A G. Controlling biofilm development in the extractive membrane bioreactor. Separation and Purification Technology, 2017, 52: 113-121

189. Skouteris G, Saroj D, Melidis P, Hai F I, Ouki S. The effect of activated carbon addition on membrane bioreactor processes for wastewater treatment and reclamation-A critical review. Bioresource Technology, 2015, 185: 399-410

190. Yeo B J, Goh S, Zhang J, Livingston A G, Fane A G. Novel MBRs for the removal of organic priority pollutants from industrial wastewaters: a review. Journal of Chemical Technology and Biotechnology (Oxford, Oxfordshire), 2015, 90(11): 1949-1967

191. Busca G, Berardinelli S, Resini C, Arrighi L. Technologies for the removal of phenol from fluid streams: a short review of recent developments. Journal of Hazardous Materials, 2008, 160(2-3): 265-288

192. Livingston A G, Arcangeli J P, Boam A T, Zhang S, Marangon M, Santos L M F D. Extractive membrane bioreactors for detoxification of chemical industry wastes: process development. Journal of Membrane Science, 1998, 151(1): 29-44

193. Livingston A G. A novel membrane bioreactor for detoxifying industrial wastewater: I. Biodegradation of phenol in a synthetically concocted wastewater. Biotechnology and Bioengineering, 1993, 41(10): 915-926

194. Xiao M, Zhou J, Tan Y, Zhang A, Xia Y, Ji L. Treatment of highlyconcentrated phenol wastewater with an extractive membrane reactor using silicone rubber. Desalination, 2006, 195(1-3): 281293

195. Ren L F, Adeel M, Li J, Xu C, Xu Z, Zhang X, Shao J, He Y. Phenol separation from phenol-laden saline wastewater by membrane aromatic recovery system-like membrane contactor using superhydrophobic/organophilic electrospun PDMS/PMMA membrane. Water Research, 2018, 135: 31-43

196. Ren L F, Ngo H H, Bu C, Ge C, Ni S Q, Shao J, He Y. Novel external extractive membrane bioreactor (EMBR) using electrospun polydimethylsiloxane/polymethyl methacrylate membrane for phenol-laden saline wastewater. Chemical Engineering Journal, 2020, 383: 123179

197. Liao Y, Goh S, Tian M, Wang R, Fane A G. Design, development and evaluation of nanofibrous composite membranes with opposing membrane wetting properties for extractive membrane bioreactors. Journal of Membrane Science, 2018, 551: 55-65

198. Jin M Y, Liao Y, Loh C H, Tan C H, Wang R. Preparation of polydimethylsiloxane-polyvinylidene fluoride composite membranes for phenol removal in extractive membrane bioreactor. Industrial \& Engineering Chemistry Research, 2017, 56(12): 3436-3445

199. Freitas Santos L M D, Hömmerich U, Livingston A G. Dichloroethane removal from gas streams by an extractive membrane bioreactor. Biotechnology Progress, 1995, 11(2): 194-201

200. Dos Santos L F, Biundo G L. Treatment of pharmaceutical industry process wastewater using the extractive membrane bioreactor. Environment and Progress, 1999, 18(1): 34-39

201. Chuichulcherm S, Nagpal S, Peeva L, Livingston A. Treatment of metal - containing wastewaters with a novel extractive membrane reactor using sulfate - reducing bacteria. Environmental \& Clean Technology, 2001, 76(1): 61-68

202. Luo W, Hai F I, Price W E, Guo W, Ngo H H, Yamamoto K, Nghiem L D. High retention membrane bioreactors: challenges and opportunities. Bioresource Technology, 2014, 167: 539-546

203. Liu Y L, Wang X M, Yang H W, Xie Y F, Huang X. Preparation of nanofiltration membranes for high rejection of organic micropollutants and low rejection of divalent cations. Journal of Membrane Science, 2019, 572(15): 152-160 
204. Choi J H, Fukushi K, Yamamoto K. A submerged nanofiltration membrane bioreactor for domestic wastewater treatment: the performance of cellulose acetate nanofiltration membranes for long-term operation. Separation and Purification Technology, 2007, 52(3): 470-477

205. Zaviska F, Drogui P, Grasmick A, Azais A, Héran M. Nanofiltration membrane bioreactor for removing pharmaceutical compounds. Journal of Membrane Science, 2013, 429: 121-129

206. Li D, Wang H. Recent developments in reverse osmosis desalination membranes. Journal of Materials Chemistry, 2010, 20(22): 4551-4566

207. Ming F T, Lee S, Xu H, Jeong K, Chong T H. Impact of salt accumulation in the bioreactor on the performance of nanofiltration membrane bioreactor (NF-MBR) + reverse osmosis (RO) process for water reclamation. Water Research, 2019, 170: 115352

208. Waszak M, Markowska-Szczupak A, Gryta M. Application of nanofiltration for production of 1,3-propanediol in membrane bioreactor. Catalysis Today, 2016, 268(15): 164-170

209. Snowdon J, Singh K S, Zanatta G. Optimization of an external nanofiltration anaerobic membrane bioreactor treating a highstrength starch-based wastewater. Journal of Environmental Engineering, 2018, 144(6): 04018032

210. Cornelissen E R, Harmsen D, Korte K, Ruiken C J, Qin J J, Oo H, Wessels L P. Membrane fouling and process performance of forward osmosis membranes on activated sludge. Journal of Membrane Science, 2008, 319(1-2): 158-168

211. Holloway R W, Achilli A, Cath T Y. The osmotic membrane bioreactor: a critical review. Environmental Science \& Technology, 2015, 1: 581-605

212. Wang X, Chang V, Tang C Y. Osmotic membrane bioreactor (OMBR) technology for wastewater treatment and reclamation: advances, challenges, and prospects for the future. Journal of Membrane Science, 2016, 504: 113-132

213. Achilli A, Cath T Y, Marchand E A, Childress A E. The forward osmosis membrane bioreactor: a low fouling alternative to MBR processes. Desalination, 2009, 239(1-3): 10-21

214. Wei J Y, Zhang J, Lay W, Cao B, Fane A G, Yu L. State of the art of osmotic membrane bioreactors for water reclamation. Bioresource Technology, 2012, 122: 217-222

215. Lay W C L, Zhang Q, Zhang J, McDougald D, Tang C, Wang R, Liu Y, Fane A G. Effect of pharmaceuticals on the performance of a novel osmotic membrane bioreactor (OMBR). Separation Science and Technology, 2012, 47(4): 543-554

216. Alturki A, Mcdonald J, Khan S J, Hai F I, Long D N. Performance of a novel osmotic membrane bioreactor (OMBR) system: flux stability and removal of trace organics. Bioresource Technology, 2012, 113: 201-206

217. Kwon D, Kwon S J, Kim J, Lee J H. Feasibility of the highlypermselective forward osmosis membrane process for the posttreatment of the anaerobic fluidized bed bioreactor effluent. Desalination, 2020, 485: 114451

218. Tan S, Acquah I, Li W. Cultivation of marine activated sludge to treat saline wastewater. Fresenius Environmental Bulletin, 2016, 25: 3134-3141

219. Lu Y, He Z. Mitigation of salinity buildup and recovery of wasted salts in a hybrid osmotic membrane bioreactor-electrodialysis system. Environmental Science \& Technology, 2015, 49(17): 10529-10535

220. Viet N D, Cho J, Yoon Y, Jang A. Enhancing the removal efficiency of osmotic membrane bioreactors: a comprehensive review of influencing parameters and hybrid configurations. Chemosphere, 2019, 236: 124363

221. Geng Y K, Wang Y, Pan X R, Sheng G P. Electricity generation and in situ phosphate recovery from enhanced biological phosphorus removal sludge by electrodialysis membrane bioreactor. Bioresource Technology, 2018, 247: 471-476

222. Wang Y K, Geng Y K, Pan X R, Sheng G P. In situ utilization of generated electricity for nutrient recovery in urine treatment using a selective electrodialysis membrane bioreactor. Chemical Engineering Science, 2017, 171(2): 451-458

223. Mamo J, García-Galán M J, Stefani M, Rodríguez-Mozaz S, Barceló D, Monclús H, Rodriguez-Roda I, Comas J. Fate of pharmaceuticals and their transformation products in integrated membrane systems for wastewater reclamation. Chemical Engineering Journal, 2018, 331: 450-461

224. Racar M, Dolar D, Karadakić K, Čavarović N, Glumac N, Ašperger D, Košutić K. Challenges of municipal wastewater reclamation for irrigation by MBR and NF/RO: physico-chemical and microbiological parameters, and emerging contaminants. Science of the Total Environment, 2020, 722: 137959

225. Díaz O, Gonzalez E, Vera L, Porlán L, Rodríguez-Sevilla J, Afonso-Olivares C, Ferrera Z, Santana Rodriguez J J. Nanofiltration/reverse osmosis as pretreatment technique for water reuse: ultrafiltration versus tertiary membrane reactor. Clean (Weinheim), 2017, 45(5): 1600014

226. Dhangar K, Kumar M. Tricks and tracks in removal of emerging contaminants from the wastewater through hybrid treatment systems: a review. Science of the Total Environment, 2020, 738: 140320

227. Beier S, Köster S, Veltmann K, Schröder H, Pinnekamp J. Treatment of hospital wastewater effluent by nanofiltration and reverse osmosis. Water Science and Technology, 2010, 61(7): $1691-1698$

228. Tam L S, Tang T W, Lau G N, Sharma K R, Chen G H. A pilot study for wastewater reclamation and reuse with $\mathrm{MBR} / \mathrm{RO}$ and MF/RO systems. Desalination, 2007, 202(1-3): 106-113

229. Comerton A M, Andrews R C, Bagley D M. Evaluation of an MBR-RO system to produce high quality reuse water: microbial control, DBP formation and nitrate. Water Research, 2005, 39(16): 3982-3990

230. Prado T, De Castro Bruni A, Barbosa M R F, Garcia S C, De Jesus Melo A M, Sato M I Z. Performance of wastewater reclamation systems in enteric virus removal. Science of the Total Environment, 2019, 678: 33-42

231. Prado T, De Castro Bruni A, Barbosa M R F, Garcia S C, Moreno L Z, Sato M I Z. Noroviruses in raw sewage, secondary effluents and reclaimed water produced by sand-anthracite filters and membrane bioreactor/reverse osmosis system. Science of the Total Environment, 2019, 646: 427-437

232. Plevri A, Noutsopoulos C, Mamais D, Makropoulos C, Andreadakis A, Lytras E, Samios S. Priority pollutants and other micropollutants removal in an MBR-RO wastewater treatment 
system. Desalination and Water Treatment, 2018, 127: 121-131

233. Plevri A, Mamais D, Noutsopoulos C, Makropoulos C, Andreadakis A, Rippis K, Smeti E, Lytras E, Lioumis C. Promoting onsite urban wastewater reuse through MBR-RO treatment. Desalination and Water Treatment, 2017, 91: 2-11

234. Li C, Cabassud C, Guigui C. Evaluation of membrane bioreactor on removal of pharmaceutical micropollutants: a review. Desalination and Water Treatment, 2014, 55(4): 845-858

235. Sahar E, David I, Gelman Y, Chikurel H, Aharoni A, Messalem R, Brenner A. The use of RO to remove emerging micropollutants following CAS/UF or MBR treatment of municipal wastewater. Desalination, 2011, 273(1): 142-147

236. Dolar D, Gros M, Rodriguez-Mozaz S, Moreno J, Comas J, Rodriguez-Roda I, Barceló D. Removal of emerging contaminants from municipal wastewater with an integrated membrane system, MBR-RO. Journal of Hazardous Materials, 2012, 239-240: 64-69

237. Aziz M, Ojumu T. Exclusion of estrogenic and androgenic steroid hormones from municipal membrane bioreactor wastewater using $\mathrm{UF} / \mathrm{NF} / \mathrm{RO}$ membranes for water reuse application. Membranes, 2020, 10(3): 37

238. Wu B, Kitade T, Chong T H, Uemura T, Fane A G. Impact of membrane bioreactor operating conditions on fouling behavior of reverse osmosis membranes in MBR-RO processes. Desalination, 2013, 311(15): 37-45

239. Wang G, Fan Z, Wu D, Qin L, Zhang G, Gao C, Meng Q. Anoxic/ aerobic granular active carbon assisted MBR integrated with nanofiltration and reverse osmosis for advanced treatment of municipal landfill leachate. Desalination, 2014, 349: 136-144

240. Wang J, Li K, Wei Y, Cheng Y, Wei D, Li M. Performance and fate of organics in a pilot MBR-NF for treating antibiotic production wastewater with recycling NF concentrate. Chemosphere, 2015, 121: 92-100

241. Hacıfazlığlu M C, Parlar İ, Pek T Ö, Kabay N. Evaluation of chemical cleaning to control fouling on nanofiltration and reverse osmosis membranes after desalination of MBR effluent. Desalination, 2019, 466: 44-51

242. Rautenbach R, Mellis R. Waste water treatment by a combination of bioreactor and nanofiltration. Desalination, 1994, 95(2): 171-
188

243. Tran T, Nguyen T, Ho H, Le D, Lam T, Nguyen D, Hoang A, Do $\mathrm{T}$, Hoang L, Nguyen T, et al. Integration of membrane bioreactor and nanofiltration for the treatment process of real hospital wastewater in Ho Chi Minh City, Vietnam. Processes (Basel, Switzerland), 2019, 7(3): 123

244. Parlar I, Hacıfazlıŏlu M, Kabay N, Pek T Ö, Yüksel M. Performance comparison of reverse osmosis (RO) with integrated nanofiltration (NF) and reverse osmosis process for desalination of MBR effluent. Journal of Water Process Engineering, 2019, 29: 100640

245. Lan Y, Groenen-Serrano K, Coetsier C, Causserand C. Fouling control using critical, threshold and limiting fluxes concepts for cross-flow NF of a complex matrix: membrane bioreactor effluent. Journal of Membrane Science, 2017, 524: 288-298

246. Lan Y, Groenen-Serrano K, Coetsier C, Causserand C. Nanofiltration performances after membrane bioreactor for hospital wastewater treatment: fouling mechanisms and the quantitative link between stable fluxes and the water matrix. Water Research, 2018, 146: $77-87$

247. Geoswami L, Kumar R V, Borah S N, Manikandan N A, Pakshirajan K, Pugazhenthi G. Membrane bioreactor and integrated membrane bioreactor systems for micropollutant removal from wastewater: A review. Journal of Water Process Engineering, 2018, 26: 314-328

248. Arola K, Hatakka H, Mänttäri M, Kallioinen M. Novel process concept alternatives for improved removal of micropollutants in wastewater treatment. Separation and Purification Technology, 2017, 186: 333-341

249. Alturki A A, Tadkaew N, Mcdonald J A, Khan S J, Price W E, Nghiem L D. Combining MBR and NF/RO membrane filtration for the removal of trace organics in indirect potable water reuse applications. Journal of Membrane Science, 2010, 365(1-2): 206215

250. Chon K, Sarp S, Lee S, Lee J H, Lopez-Ramirez J A, Cho J. Evaluation of a membrane bioreactor and nanofiltration for municipal wastewater reclamation: trace contaminant control and fouling mitigation. Desalination, 2011, 272(1-3): 128-134 